\title{
The Impact of China's Trade Liberalisation on the Greenhouse Gas Emissions of WTO Countries
}

Levitt, Clinton J.; Saaby, Morten; Sørensen, Anders

\author{
Document Version \\ Accepted author manuscript \\ Published in: \\ China Economic Review \\ DOI: \\ 10.1016/j.chieco.2018.10.012 \\ Publication date: \\ 2019 \\ License \\ CC BY-NC-ND
}

Citation for published version (APA):

Levitt, C. J., Saaby, M., \& Sørensen, A. (2019). The Impact of China's Trade Liberalisation on the Greenhouse Gas Emissions of WTO Countries. China Economic Review, 54, 113-134.

https://doi.org/10.1016/j.chieco.2018.10.012

Link to publication in CBS Research Portal

\section{General rights}

Copyright and moral rights for the publications made accessible in the public portal are retained by the authors and/or other copyright owners and it is a condition of accessing publications that users recognise and abide by the legal requirements associated with these rights.

\section{Take down policy}

If you believe that this document breaches copyright please contact us (research.lib@cbs.dk) providing details, and we will remove access to the work immediately and investigate your claim.

Download date: 26. Apr. 2023



\section{The Impact of China's Trade Liberalisation on the Greenhouse Gas Emissions of WTO Countries}

\section{Clinton J. Levitt, Morten Saaby, and Anders Sorensen}

Journal article (Accepted manuscript*)

\section{Please cite this article as:}

Levitt, C. J., Saaby, M., \& Sørensen, A. (2019). The Impact of China's Trade Liberalisation on the Greenhouse Gas Emissions of WTO Countries. China Economic Review, 54, 113-134.

https://doi.org/10.1016/j.chieco.2018.10.012

\section{DOI: 10.1016/j.chieco.2018.10.012}

* This version of the article has been accepted for publication and undergone full peer review but has not been through the copyediting, typesetting, pagination and proofreading process, which may lead to differences between this version and the publisher's final version AKA Version of Record.

Uploaded to CBS Research Portal: July २०19

(C) 2019. This manuscript version is made available under the CL-BY-NC-ND 4.0 license http://creativecommons.org/licenses/by-nc-nd/4.0/ 


\title{
The Impact of China's Trade Liberalisation on the Greenhouse Gas Emissions of WTO Countries *
}

\author{
Clinton J. Levitt ${ }^{\mathrm{a}}$, Morten Saaby ${ }^{\mathrm{b}}$ and Anders Sørensen ${ }^{\dagger c}$

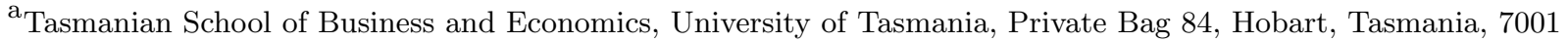 \\ Australia. Email: Clinton.Levitt@Utas.edu.au \\ ${ }^{\mathrm{b}}$ Department of Business and Economics,University of Southern Denmark,Campusvej 55, 5230 Odense M, \\ Denmark. Email:mosp@sam.sdu.dk \\ ${ }^{\mathrm{c}}$ Department of Economics, Copenhagen Business School, Porcelænshaven 16A, 2000 Frederiksberg, Denmark. \\ Email: as.eco@cbs.dk
}

October 1, 2018

\begin{abstract}
We examine the effects of China's trade liberalisation, post entry into the WTO, on the greenhouse-gas (GHG) emissions of its trading partners. Using complementary estimators we establish that China's liberalised trade had significant effects on the GHG emissions of its trading partners. Increased exposure to Chinese exports increased the growth of consumption-based emissions while reducing productionbased emission. The increase in consumption-based emissions was larger than the decrease in production emissions. Consumption emissions increased both through a scale effect (consumption increased) and a composition effect(consumption became more emissions intensive). Decomposition analysis suggests that the link between exposure to Chinese exports and the increase consumption-based emissions is the emissions embodied in imports: The emissions embodied in imports increased and imports became more emissions intensive. The increase in imported emissions was not offset by a reduction in domestic production of emissions either in final consumption goods or exports. (JEL: Q53, Q54, Q55).
\end{abstract}

*All three authors would like to thank the Rockwool Foundation for financial support (more information about the Rockwool Foundation can be found at http://www.rockwoolfonden.dk/home). The research reported in this paper is the sole responsibility of the authors and do not necessarily represent the views of the Rockwool foundation.

$\dagger$ Corresponding author. 


\section{Introduction}

An important issue concerning trade and the environment is the potential for trade liberalization to have detrimental effects on environmental quality. One concern is that liberalised trade could exacerbate the negative externalities contributing to climate change via greater scale of economic activity or relocating production to regions with emission intensive production. In this paper, we examine the effect of a significant trade liberalization event on greenhouse gas (GHG) emissions: China's admission to the World Trade Organization (WTO) in December 2001. This event marked the opening of the Chinese economy and the growth of Chinese exports to world markets.

We study the effects of China's entry into the WTO and subsequent growth of exports on the GHG emissions of China's trading partners. There are a number of mechanisms through which Chinese liberalised trade can effect the emissions of its trading partners. For example, shrinking trade barriers and lower transaction costs reduce the costs of Chinese produced goods allowing for more consumption. Lower trade barriers also alter relative prices causing consumers to increase their demand for lower priced imports, perhaps more GHG-intensive Chinese goods, by substituting away from potentially higher-priced, but less GHG-intensive goods, produced either domestically or abroad. Both have the potential to increase aggregate GHG emissions.

There is also the link between environmental policy and international trade. Stringent environmental regulations could increase GHG emissions in regions with relatively less-stringent regulations through international trade. Reducing trade barriers or transactions costs change relative prices which create incentives for firms to shift production of emission intensive goods, or other parts of the production chain, to places with less environmental regulation [see Copeland and Taylor (2005), Aichele and Felbermayr (2015) and Levinson (2010)]. Easing trade barriers reduces the costs of offshoring potentially making the pollution haven hypothesis more likely. If these effects or the demand and income effects are relatively large then the outcomes of national policies or international agreements aimed at reducing GHG emissions could be made less effective. GHG emissions contributing to climate change are a global externality: The consequences of growing emission levels are global because GHG emissions are transboundary.

China's admission into the WTO provides an excellent opportunity to study the effects of a significant trade liberalising event on GHG emissions. We focus on China's entry into the WTO because China is the largest exporting developing country, a significant contributor to the large increase in low-wage countries' share of the developed world's aggregate imports (see Bloom et al. (2016)), the second largest source of GHG emissions, and China's admission into the WTO enables us to plausibly identify the causal effects of trade liberalisation on GHG emissions. In fact, the substantial growth of China's international trade has spurred a growing research agenda looking into its economic effects on China's trading partners. A number of recent studies examined the impact on economic growth [Andersen et al. (2014)], on labour markets [Autor et al. 
(2013) and Han et al. (2012)] as well as on innovation and industry dynamics [Bloom et al. (2016) and Utar and Ruiz (2013)]. We examine the related question of what was the effect of Chinese liberalised trade on the GHG emissions of China's trading partners? For example, did liberalised Chinese trade cause the imports of its trading partners to be more emissions intensive? Did countries respond to China's trade liberalisation by importing more emissions? Was there an effect on the emission intensity of domestic production? Is there empirical evidence that countries offshored emissions embodied in intermediate production to China? What was the aggregate effect on the GHG emissions of China's trading partners? By answering these questions and related ones, we provide additional insight into the various issues concerning the relationship between internationally trade and GHG emissions.

We compute various measures of GHG emissions for 13 years covering 1996-2007 using data from the World Input-Output Database (WIOD). ${ }^{1}$ The WIOD consists of a series of linked input-output tables for 35 sectors across 39 countries plus China [see Timmer et al. (2015) and Dietzenbacher et al. (2013)]. Importantly, the information in the input-output tables can be linked to air emissions accounts containing information on carbon dioxide $\left(\mathrm{CO}_{2}\right)$, methane $\left(\mathrm{CH}_{4}\right)$, and nitrous oxide $\left(\mathrm{N}_{2} \mathrm{O}\right)$ for each sector in each country. The advantage of using the data in the WIOD is that it allows us to track the flow of GHG emissions along global production chains, from final consumers back to the country of origin, even if the production process passes through many countries and sectors. Consequently, the measures of GHG emissions we compute include the emissions content of international traded intermediate goods.

We use the data in a number of complementary empirical strategies to estimate the effects of liberalised Chinese trade on GHG emissions. We first estimate long-difference regression models using different specifications of the OLS estimator. We take advantage of the panel structure of our data to estimate various fixed effect specifications. The robustness of the OLS results are investigated by using alternative estimators that rely on different identification arguments to identify the causal relationship between Chinese trade liberalisation and GHG emissions in importing countries. First, we exploit the fact that not all domestic sectors were exposed to intensified Chinese imports to estimate difference-in-difference estimators. Second, a concern raised in previous empirical studies is that trade and environmental quality are likely determined simultaneously [see Frankel and Rose (2005) for example]. Consequently, we use an initial conditions instrumental variables strategy to address this concern as well as related ones.

We find empirical evidence that China's liberalised trade has had substantial effects on the GHG emissions of its trading partners. Increase trade with China tended to increase the growth of country-sector consumption-based emissions and lower the growth of production-based emissions in importing countries. The cause of the growing gap between consumption and production emissions was large growth of GHG emissions embodied in imports relative to the emissions embodied in domestically produced final consump-

\footnotetext{
${ }^{1}$ We use the 2013 release of the WIOD because the data begins in 1995 and includes environmental accounts from 1995 to 2007.
} 
tion goods. Both scale effects and composition effects contribute to the growth of consumption emissions. Growth in the share of imports from China tended to increase consumption and imports and both became more emission intensive.

These results suggest that China's liberalised trade is one factor explaining the increase in GHG emissions embodied in goods consumed by developed countries as well as the growing gap between production and consumption emissions observed in developed countries over the last decades. Moreover, this study illustrates that trade policies can have important effects on GHG emissions that are not included in most national GHG accounts as well as distort the progress reporting of GHG emissions reductions under the Kyoto agreements. ${ }^{2}$

There are studies that examine the impact of Chinese liberalised trade on GHG emissions both within China and in a global context. For example, using an environmental computable general equilibrium (CGE) model, Vennemo et al. (2008) concludes that China's entry into the WTO reduced carbon emissions in China, whereas Xu and Dietzenbacher (2014) find that total carbon emissions embodied in exports from China to the world market increased by 207 percent between 1995 and 2007 . We complement these studies by providing the first econometric analysis of the impact of China's liberalised trade on the GHG emissions on its trading partners. In particular, we complement Xu and Dietzenbacher (2014) by linking the changes in China's exported emissions to changes to the emission structure of China's trading partners.

Our study also contributes to the literature quantifying carbon emissions embodied in international trade. For example, Davis and Caldeira (2010) report that 23 percent of global carbon emissions were traded internationally in 2004. Moreover, there is evidence that emissions embodied in international trade are increasing: Peters et al. (2011) find that emissions embodied in international trade increased from 20 percent in 1990 to 26 percent in 2008. Perhaps more importantly, they find that the net transfer of emissions from the developing world to developed countries increased by almost 300 percent. Our study finds empirical evidence that one factor causing the transfer of emissions from developing countries to developed countries is trade liberalisation. Understanding the mechanisms driving the transfer of GHG emissions among countries is important and may assist in the design of future climate and environmental policies. ${ }^{3}$

The remainder of the paper is organised as follows. We describe the data and the construction of the various measures of GHG emissions in section 2. In section 3, we discuss our empirical strategies and present the results. Section 4 concludes.

\footnotetext{
${ }^{2}$ The Kyoto agreement requires participating countries to track territorial emissions which are essential production-based emissions.

${ }^{3}$ Such net transfer of emissions is not included in the reporting requirement under the Kyoto agreements.
} 


\section{Computing Trade Flows and GHG Emissions}

\section{$2.1 \quad$ Data}

Estimating the effects of China's liberalised trade on the GHG emissions of its trading partners requires tracking the GHG emissions embodied in trade across sectors and between countries. All measures must account for trade in intermediate goods. Moreover, trade and emissions must be computed for a large set of countries using data constructed consistently across countries and over time. Our main source of data is the World Input-Output database (WIOD) [Timmer et al. (2015) and Dietzenbacher et al. (2013)]. ${ }^{4}$ The WIOD consists of world input-output tables (WIOT) covering the period 1995 to 2011, for 35 sectors in 40 countries, including all EU-27 countries as well as 13 other major countries: Australia, Brazil, Canada, China, India, Indonesia, Japan, Mexico, Russia, South Korea, Taiwan, Turkey, and the United States. These countries accounted for approximately 85 percent of world GDP in 2008. Consequently, our measures account for GHG emissions embodied in the majority of traded goods and services.

We use the data in the WIOD because it was constructed using harmonized sector classification meaning that the manufacturing sectors are defined similarly across the 39 importing countries plus China. The WIOT were constructed by combining national input-output tables with bilateral international trade data following the conventions of the System of National Accounts. Each country's WIOT contain data for 35 sectors based on the NACE rev. 1 (ISIC rev. 2) nomenclature. The sectors include agriculture, mining, construction, utilities, 14 manufacturing industries and 17 service industries. Each WIOT reports the total output produced by each sector as well as the output that was used in final consumption by households, industries, and governments, in each country [see Timmer et al. (2015) and Dietzenbacher et al. (2013)]. We analyse the 14 manufacturing sectors in our empirical work because trade in manufactured goods had the most dynamic response to China's trade liberalisation and embodies the bulk of traded emissions. In addition, we investigate if Chinese liberalised trade had an effect on offshoring emission in manufacturing production. ${ }^{5}$

The data in the WIOT are reported in both current-year and previous-year prices. This unique feature means that a price index can be constructed to control for changes in prices required for computing GHG emission intensities. Tracking year-to-year changes in intensities requires controlling for changes in prices to ensure we track changes in emissions and not changes in relative prices. Suppose that Canada imported the same amount of goods from China in 1995 and 1996 as well as emitted the same amount of GHGs in

\footnotetext{
${ }^{4}$ There does exist alternative databases. The Eora multi-region input-output (MRIO) database is one example. The Eora database has a larger set of countries but the sectors are not harmonised. There is a smaller version of the database, Eora26, that is harmonized, but consists of nine sectors. Moran and Wood (2014) compared various databases and concluded not one is better than the others. The WIOD also has the advantage of containing complementary socio-economic data at the same country-sector level. In addition, the WIOD are reported in both current-year and previous-year prices.

${ }^{5}$ Note, however that we compute emissions for all 35 sectors and estimate models using all 35 sectors as robustness checks; the results are reported in the appendix.
} 
those years. The emission intensity of Canadian imports from China has not changed. However, if prices increased over this period, then using values in current prices would result in decreasing emission intensities when they should be unchanged.

For each sector in each country we use a standard chaining method applied to a Paasche-type index to calculate year-to-year changes in prices. Consider a sector located in Canada: The index for the price change between 1995 and 1996 is computed by first taking the ratio of the 1996 output in 1996 prices to 1996 output in 1995 prices. Next, we construct the same index for the price change between 1996 and 1997: The ratio of the 1997 output in 1997 prices to 1997 output in 1996 prices. The 1996 ratio is multiplied by the equivalent ratio for 1996. We have now computed an index of how prices have changed since 1995 which we can use to control for changes in prices at the country and sector level [Xu and Dietzenbacher (2014) used a similar chaining procedure using the WIOT].

In addition to tracking international trade between countries and across sectors, the WIOD also includes an environmental database consisting of energy and air emission accounts which can be linked back to the input-output tables at the sector-country level. These air emission data provide a link between the economic activities and GHG emissions of each sector in each country. The main source of information for the energy accounts in the WIOD are the energy balances maintained by the International Energy Agency (IEA). The emission factors were obtained from the 2006 IPCC Guidelines for National Greenhouse Gas Inventories as well as from United Nations Framework Convention on Climate Change (UNFCCC) emission reporting. We include the three main greenhouse gases in our measure of emissions: $\mathrm{CO}_{2}, \mathrm{CH}_{4}$ and $\mathrm{N}_{2} \mathrm{O} . \mathrm{CH}_{4}$ and $\mathrm{N}_{2} \mathrm{O}$ were converted to $\mathrm{CO}_{2}$ equivalents using conversion factors derived from the global warming potential (GWP) index. The GWP is an index of the amount of warming a gas causes over a period of time (typically 100 years). The GWP index for $\mathrm{CH}_{4}$ is 25 and for $\mathrm{N}_{2} \mathrm{O}$ the index is 298.

The WIOD also include Socio-Economic accounts. We use the data from these accounts to construct control variables for each sector in each country. The tables in the Socio-Economic accounts are complementary to the data in the WIOT. Both the input-output tables and the Socio-Economic accounts were constructed using the same sector classification making it possible to collect data for the identical manufacturing sectors in the input-output tables [Timmer et al. (2015) and Dietzenbacher et al. (2013)]. We constructed real output, the share of capital in real output, labour hours and the share of low skilled labour in total labour hours to use as control variables in the empirical models.

\section{$2.2 \quad$ Trade}

We compute various measures of a sector's exposure to Chinese trade. We use the import share approach developed by Bernard et al. (2006) to construct a measure of exposure based on China's share of aggregate imports. The measure is computed as Chinese imports to country $i$, originating from sector $s$ in year $t$, 
denoted by $I M P_{i s t}^{C H N}$, as a share of sector $s$ 's aggregate world imports in country $i$, denoted by $I M P_{i s t}^{W}$ [a similar measure was also used by Bloom et al. (2016)]. Note that "world" refers to the set of 40 countries for which data is available in the WIOD. So, exposure to Chinese trade at the country-sector level is

$$
M_{i s t}^{C H N}=\frac{I M P_{i s t}^{C H N}}{I M P_{i s t}^{W}}
$$

We also compute measures of trade based on the level Chinese imports in domestic consumption and production. These additional statistics measure changes in the level of Chinese imports relative to the level of domestic consumption or production to provide information concerning scale effects. These measures of trade exposure are computed by normalising $I M P_{i s t}^{C H N}$ by domestic production, $D_{i s t}$, and by aggregate domestic consumption, $C_{i s t}$. Note that $C_{i s t}$ is computed as domestic production plus imports minus exports. All of these measures were computed using data from the WIOTs.

\subsection{GHG Emissions}

We compute two aggregate measures of emissions: a production-based measure and a consumption-based measure. The difference between the two aggregate measures of emissions is how each accounts for the emissions embodied in international trade. Computing both measures provides a complete picture of any changes in the structure of GHG emissions since we account for all sources of emissions.

The production-based measure accounts for the GHG emissions emitted into the atmosphere from the domestic production of goods and services irrespective of whether they are consumed domestically or exported. Production-based measures only include the GHG emissions that are emitted from production within a specific country and do not include GHG emissions from the production of intermediate goods that were imported for use in domestic production. Moreover, production-based measures do not include emissions from the production of imported final consumption goods.

Consumption-based emissions include emissions from the production of goods and services which are consumed domestically irrespective of where they were produced. Consumption emissions are difficult to compute because they include emissions emitted abroad from producing goods that are imported for use as intermediate inputs or as final consumption goods. Domestically produced goods and services that are exported are not included in consumption-based measure of GHG emissions.

\subsubsection{Production-Based Emission}

Production-based emissions are straightforward to compute given the data available in the WIOD. Let $e_{i s t}$ denote the emission factor for sector $s$ located in country $i$ in year $t$ and $Z_{\text {ist }}$ denote the total amount of output produced in that sector. Sector s's production emissions in country $i$ in period $t$ is $G H G_{i s t}^{p}=e_{i s t} Z_{i s t}$. 


\subsubsection{Consumption-Based Emissions}

Computing consumption-based GHG emissions requires accounting for all of the GHG emissions emitted from the production of goods and services consumed by domestic consumers. For example, to compute the emissions associated with the consumption of good $y$, we must track all of the GHGs emitted during each stage of good $y$ 's production, including the emissions associated with producing intermediate goods $x$ used in the production of good $y$. This accounting is complicated because the intermediate inputs used to produce good $y$ may have come from different sectors in different countries. Moreover, the intermediate inputs themselves could have been produced using intermediate goods imported from other countries. This chain of emissions can go on and on through global production chains. A further complication is that each economic sector, in each country, likely have different emission intensities. Therefore, accurately computing the emissions embodied in the flow of intermediate goods, over all stages of good y's production, requires assigning the appropriate emission intensities at each stage of the production chain. If intermediate input $x$ was used to produce good $y$ and input $x$ used additional inputs from sectors in countries $A$ and $B$, then the emission intensities from those sectors in the two countries must be used to compute emissions caused by consuming good $y$.

We use global multi-regional input-output analysis to compute consumption emissions. ${ }^{6}$ We begin with a system of equations which describe the flow of goods and services between sectors and across countries:

$$
\left[\begin{array}{c}
\mathbf{z}_{1} \\
\mathbf{z}_{2} \\
\mathbf{z}_{3} \\
\vdots \\
\mathbf{z}_{40}
\end{array}\right]=\left[\begin{array}{ccccc}
\mathbf{A}_{11} & \mathbf{A}_{12} & \mathbf{A}_{13} & \cdots & \mathbf{A}_{1,40} \\
\mathbf{A}_{21} & \mathbf{A}_{22} & \mathbf{A}_{23} & \cdots & \mathbf{A}_{2,40} \\
\mathbf{A}_{31} & \mathbf{A}_{32} & \mathbf{A}_{33} & \cdots & \mathbf{A}_{3,40} \\
\vdots & \vdots & \vdots & \ddots & \vdots \\
\mathbf{A}_{40,1} & \mathbf{A}_{40,2} & \mathbf{A}_{40,3} & \cdots & \mathbf{A}_{40,40}
\end{array}\right] \times\left[\begin{array}{c}
\mathbf{z}_{1} \\
\mathbf{z}_{2} \\
\mathbf{z}_{3} \\
\vdots \\
\mathbf{z}_{40}
\end{array}\right]+\left[\begin{array}{c}
\sum_{j=1}^{40} \mathbf{y}_{\mathbf{1 j}} \\
\sum_{j=1}^{40} \mathbf{y}_{\mathbf{2}} \\
\sum_{j=1}^{40} \mathbf{y}_{\mathbf{3}} \\
\vdots \\
\sum_{j=1}^{40} \mathbf{y}_{\mathbf{4 0 j}}
\end{array}\right]
$$

where $\mathbf{z}_{i}$ ( $i$ indexes the 40 countries) is a $(35 \times 1)$ column vector of total output for each of the 35 sectors; each $\mathbf{A}_{i j}$ ( $i$ indexes the consuming country and $j$ indexes the producing country) is a $(35 \times 35)$ matrix of normalized input coefficients where each column of the matrix reports the normalized input from the sectors in country $j$ required to produce 1 unit of output by the sectors in country $i$; $\mathbf{y}_{\mathbf{1}}$ is a $35 \times 1$ vector of each sector's output produced in a given country and consumed by the other countries. The product $\mathbf{A z}$ is the total amount of intermediate goods and services. The structure of this input-output data is the same one used in the WIOD.

\footnotetext{
${ }^{6}$ There are good in-depth analysis of multi-region input-output analysis. For those relating to emissions accounting see Wiedmann et al. (2007), Wiedmann (2009). For a specific example of using input-output tables to compute consumption emissions see Levitt et al. (2015).
} 
The system of equations can be written in the more familiar form:

$$
\mathbf{z}=(\mathbf{I}-\mathbf{A})^{-1} \mathbf{Y}
$$

where $\mathbf{I}$ is block identity matrix with each block a $35 \times 35$ identity matrix, $\mathbf{A}$ is the block matrix in equation 1 , and $\mathbf{Y}$ is the vector of final consumption in equation 1. The matrix $(\mathbf{I}-\mathbf{A})^{-\mathbf{1}}$ is called the Leontief inverse and represents the gross output that is generated along all stages of producing of one unit of a consumption good.

Computing consumption emissions requires assigning the correct emission factor for each of the 35 sectors in the 40 countries. The emission factors for each sector located in each country are collected in the matrix e:

$$
\mathbf{e}=\left[\begin{array}{ccccc}
\mathbf{e}_{1} & \mathbf{e}_{2} & \mathbf{e}_{3} & \cdots & \mathbf{e}_{40} \\
\mathbf{e}_{1} & \mathbf{e}_{2} & \mathbf{e}_{3} & \cdots & \mathbf{e}_{40} \\
\mathbf{e}_{1} & \mathbf{e}_{2} & \mathbf{e}_{3} & \cdots & \mathbf{e}_{40} \\
\vdots & \vdots & \vdots & \ddots & \vdots \\
\mathbf{e}_{1} & \mathbf{e}_{2} & \mathbf{e}_{3} & \cdots & \mathbf{e}_{40}
\end{array}\right]
$$

where $\mathbf{e}_{\mathbf{i}}$ is a block matrix where each block is a $35 \times 35$ diagonal matrix consisting of emission factors for each sector in country $i$. Define $\mathbf{Y}^{\mathbf{H}}$ to be a vector containing final domestic consumption of domestically produced goods and imported goods. Consumption-based emissions are calculated as the Hadamard product of $\mathbf{e}$ and the Leontief matrix:

$$
\mathbf{G H G}^{c}=\left[\mathbf{e} \circ(\mathbf{I}-\mathbf{A})^{-1}\right] \mathbf{Y}^{\mathbf{H}}
$$

where $\mathbf{G H G}^{c}$ is a block matrix with each block, $\mathbf{G H G}_{i}^{c}$, being a $(35 \times 1)$ vector of consumption emissions for each sector in country $i$. Specifically, the consumption-based emissions for sector $s$ in country $i$ in period $t$ is

$$
G H G_{i s t}^{c}=\sum_{j=1}^{40} \sum_{k=1}^{35} e_{k t}^{j} i a_{s k t}^{i j} y_{j k t}^{h}
$$

where $j$ identifies the producing country, $k$ is producing sector, and $i a_{s k t}^{i j}$ is the $s k$ 'th element of the Leontief inverse between countries $i$ and $j$. We compute this measure for each of the 13 years covering 1995-2007.

One way to think about the measure $G H G_{i s t}^{c}$ is that it contains the consumption-based emissions from producing final consumption goods that have been adjusted to include the GHG emissions emitted from producing intermediate inputs. Importantly, the emissions were determined using country, sector, and time specific emission factors. This means, for example, if the electronic manufacturing sector in China used intermediate inputs produced in another manufacturing sector in India, then the emission factor used to calculate consumption emissions is the emission factor of the manufacturing sector in India. So, even in 
the case of intermediate goods, appropriate emission factors are used to compute aggregate consumption emissions.

We compute additional measures of emissions. We compute the consumption-based emissions associated with imported final consumption goods, $\mathbf{G H G}{ }^{m}$, as well as the emissions from domestically produced final consumption goods, $\mathbf{G H G}^{d}$ which also includes emissions embodied in intermediate production. These two measures help identify any sources of change in the growth of consumption-based emissions. We also compute the emissions in domestically produced exports, $\mathbf{G H G}^{\mathbf{x}}$.

In addition to emissions levels, we also compute emission intensities to study composition changes. We compute the emission intensity of consumption and production (complementary to $\mathbf{G H G} \mathbf{H}^{c}$ and $\mathbf{G} \mathbf{H G}{ }^{p}$ ). We also compute a measure of the emission intensity of domestically produced goods that are consumed domestically (complementary to $\mathbf{G H G}^{d}$ ). Finally, we compute a GHG-import intensity measure computed as the ratio of GHG emissions to aggregate imports (complementary to $\mathbf{G H G}{ }^{m}$ ) which measures the emission intensity of imports. ${ }^{7}$

\section{Trade Liberalization and Emissions}

We empirically investigate the potential effects that liberalised trade can have on GHG emissions by analysing China's admission to the WTO. We first focus on aggregate measure of emissions in CHina's trading partners. We then decompose the aggregate measures into their components to analyse the sources of changes to aggregate emissions and investigate links between Chinese trade and emissions. We analyse both emissions levels and emission intensities.

\subsection{Descriptive Analysis}

As a precursor to introducing our empirical strategies and discussing the results, we first present a descriptive illustration of the changes that occurred to GHG emissions and international trade after China's inclusion into the WTO. Figure 1 illustrates Chinese export trade in manufactured goods. Chinese export trade had been growing since at least 1995; however, the rate at which Chinese exports grew increased substantially after 2001 (illustrated in panel 1(a)). In the six years prior to 2001, Chinese manufacturing exports grew by about 83 percent, whereas in the six years after 2001, Chinese exports grew by about 212 percent. Countries were importing Chinese goods at an increasing rate after China was admitted to the WTO. Panel 1(b) shows that the growth of Chinese exports translated into China claiming a larger share of world imports. ${ }^{8}$ In the

\footnotetext{
${ }^{7}$ We do not report an emission intensity measure for emission embodied in exports. We are working at the sector level which implies that the emission intensity of domestic production used for final domestic consumption is equal to the emission intensity of domestic production of exported goods. They are the same because the emission factors are applied to domestic sectors. Practically, exports and domestic production originate from the same rows in the WIOT.

${ }^{8}$ Panel 1(b) shows the average annual share of Chinese imports across each of the 14 manufacturing sectors in the 39 countries.
} 


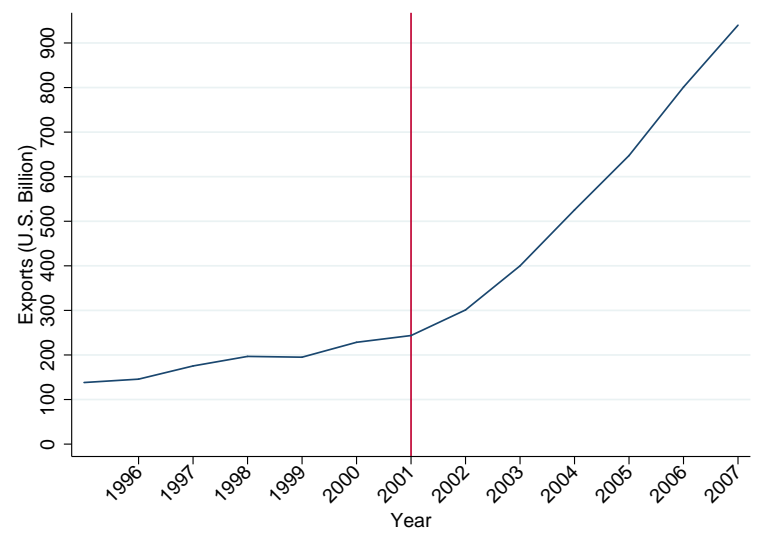

(a) Real Chinese Manufacturing Exports

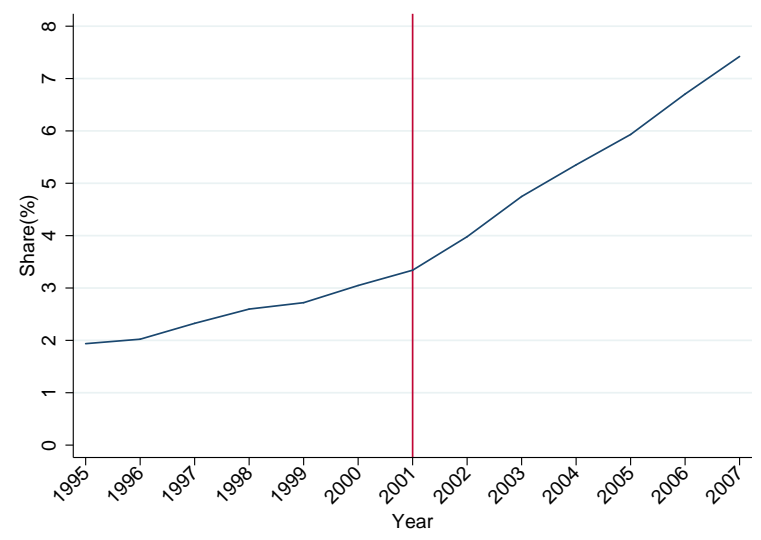

(b) China's Share of Imports

Figure 1: China's Export Trade, 1995-2007

six years after China was admitted to the WTO, its share of world imports grew by almost 120 percent, whereas in the six years prior, China's share of world imports grew by 55 percent. Countries were importing more goods from China and this growth translated into Chinese goods comprising a larger share of world imports.

If the changes observed in China's international trade after it was admitted to the WTO had an effect on GHG emissions then we should observe changes to various measures of emissions around the time that China was admitted. We report two measures of imported emissions in Figure 2. Panel 2(a) reports the average annual GHG emissions imported by each of the 39 countries. We report the averages for both developed and developing countries (China is not included in the group of importing countries). ${ }^{9}$ Consistent with the increase in Chinese exports observed in Figure 1, average imported GHG emissions increased substantially after China was admitted to the WTO. Imported emissions grew by approximately 23 percent between 1995 and 2001, whereas in the six years after China was admitted to the WTO, imported emission grew by almost 64 percent. Developed countries experienced larger growth of imported emissions compared to developing countries.

Panel 2(b) reports the average emissions-to-import intensity ratio across all sectors and the 39 countries (not including China). The ratio has a U-shaped pattern for both developed and developing countries. The ratio decreased from a little less than 120 tonnes $/ \$$ million imports to less than 90 Tonnes $/ \$$ million imports. However, by 2000, this trend reversed and the ratio began to increase so that by the end of 2007, the ratio was greater than the 1995 levels for both groups of countries. In aggregate, the ratio grew by 23 percent in the six years between 2002 and 2007.

\footnotetext{
${ }^{9}$ We provide a scatterplot of imported emissions by all countries in the appendix
} 


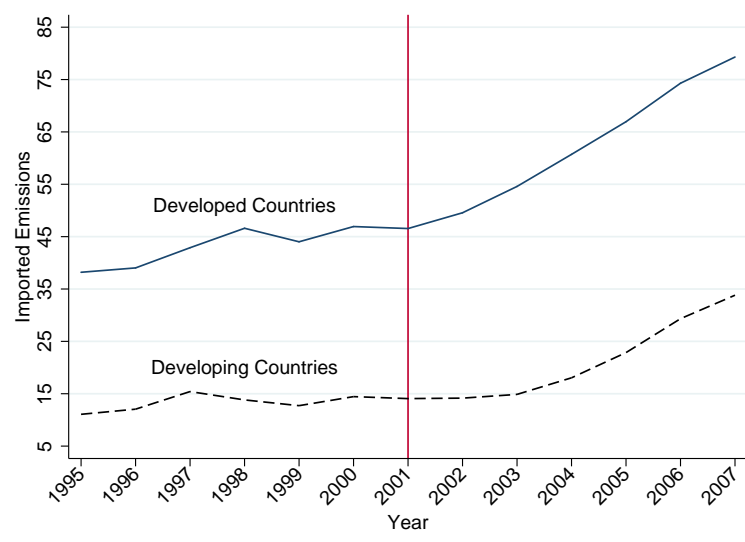

(a) Imported GHG Emissions (Million Tonnes)

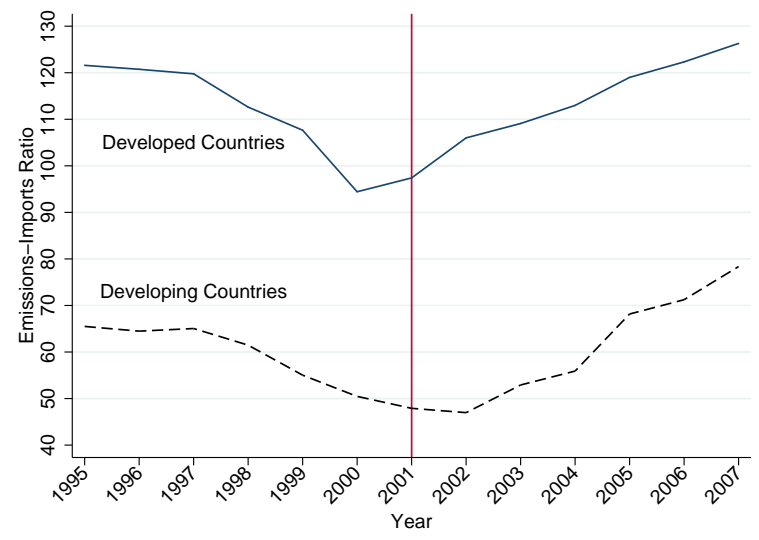

(b) GHG Emissions-Imports Intensity (Tonnes/Million \$U.S.)

Figure 2: Imported GHG Emissions, 1995-2007

The emissions embodied in imports across the 39 countries reported in Figure 2 suggest a positive correlation between the increase in Chinese exports and the emissions embodied in the imports of its trading partners. These results are consistent with the changes in Chinese domestic production reported in Duan and Jiang (2017). ${ }^{10}$ Duan and Jiang (2017) show that China's export emission intensity decreased between 1995 and 2001, but started to increase in 2001. After 2004, the emission intensity of exports again started decrease, but at slower rate than prior to China's entry into the WTO. The increase in China's export emissions intensity and eventual slower rate of decrease was driven by a negative technique effect: Chinese production shifted to towards more emission intensive production (Duan and Jiang (2017)). The shift to more emissions intensive production occurred as China's trade in intermediate goods increased from less than 5 percent of world intermediate production to a just over 15 percent in 2007.

Do we observe correlations in the aggregate measures of emissions? We report both measures in figure $3 .{ }^{11}$ There was a substantial increase in consumption emissions beginning in 2002 for both developed countries and developing countries. In contrast, the production emissions of developed countries tended to decline beginning around 2000. The growth of production emissions for developing countries appear to be roughly unchanged over the sample period. The increase in consumption emissions is consistent with the increase in Chinese trade and with the measures of imported emissions after China was admitted to the WTO.

These descriptive illustrations suggest a strong correlation between China's entry into the WTO and subsequent trade liberalisation with traded emissions, production-based emissions and consumption-based emissions. Moreover, complementary research has shown that there is a correlation between China's shift

\footnotetext{
${ }^{10}$ Note that Duan and Jiang (2017) also used data from the WIOD for their analysis of China's GHG emissions.

${ }^{11}$ The two panels in figure 3 report average emissions across the 39 countries. We report aggregate emissions for both developing and developed countries in the appendix in figure A3.
} 


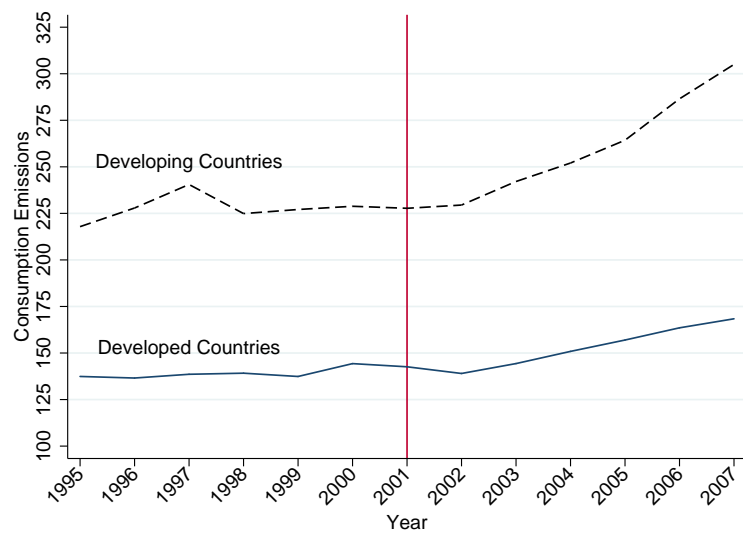

(a) Consumption-based Emission

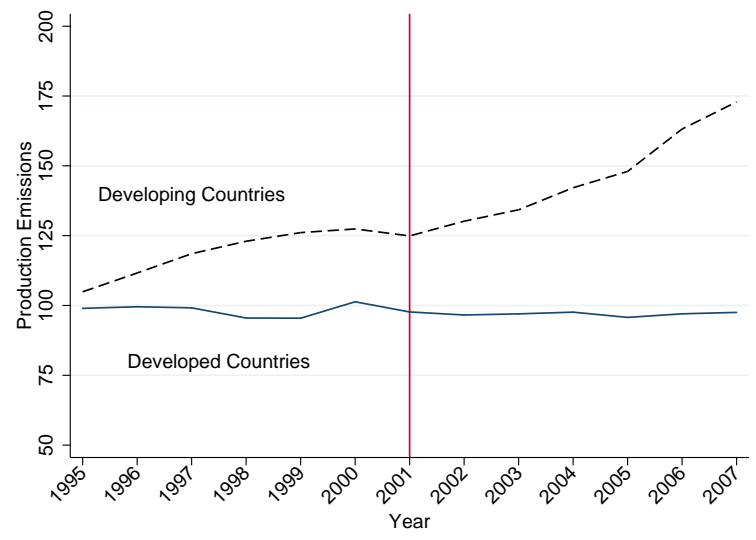

(b) Production-based Emissions

Figure 3: GHG Emissions, 1995-2007

to more emission intensive production and the increase in China's export of intermediate goods (Duan and Jiang (2017)). These descriptive links are only suggestive and not evidence of causation: Our objective is to empirically establish the causal effects of trade liberalisation on emissions. In the next section, we employ various complementary empirical strategies to explore the causal effect of China's liberalised trade on GHG gas emissions in the next section.

\subsection{Empirical Models and Results}

\subsubsection{Baseline Models and Results}

Our analysis focuses on the empirical link between the growth of Chinese trade after entry into the WTO and the GHG emissions of China's trading partners. Consider a country-sector level equation for GHG emissions with dependent variable $Y_{\text {ist }}$ where $s$ denotes the sectors in each country $i$ in year $t$ and $Y$ represents various measures of emissions. The regression equation is:

$$
Y_{i s t}=\beta_{1} M_{i s t}^{C H N}+\beta_{2} D_{i}^{d e v} \times M_{i s t}^{C H N}+x_{i s t}^{\prime} \gamma+\mu_{i t}+\eta_{i s}+\epsilon_{i s t} .
$$

The variable of interest is China's share of each sector's aggregate imports in each country, $M_{i s t}^{C H N}$. To explore potential differentiated responses between developing and developed countries we include an interaction term, $D_{i}^{d e v} \times M_{i s t}^{C H N}$, where $D_{i}^{d e v}=1$ if country $i$ is a developing country. The model includes a vector of sectorcountry specific control variables. The vector includes real output, capital's share of real output, total labour hours, and share of low-skilled labour in total labour. The model also includes a set of interacted country and year dummy variables, $\mu_{i t}$, to capture time-varying country-specific macroeconomic shocks as well as 
sector-country fixed effects, $\eta_{i s}$, which captures time-invariant differences between sectors across countries and an error term, $\epsilon_{i s t}$.

We are interested in studying how the rapid growth of Chinese imports, after it was admitted into the WTO, affected the growth of various measures of GHG emissions. Therefore, we use OLS to estimate equation (5) in long-differences using two non-overlapping six-year differences 2001-2007 and 1995-2001. The regression model in long-differences is:

$$
\Delta Y_{i s t}=\beta_{1} \Delta M_{i s t}^{C H N}+\beta_{2} D_{i s t}^{d e v} \times \Delta M_{i s t}^{C H N}+\Delta x_{i s t}^{\prime} \gamma+\Delta \mu_{i t}+\Delta \epsilon_{i s t}
$$

where $\Delta$ denotes the six-year difference operator. Using long-differences sweeps out the country-sector fixed effects and has the benefit of dealing with potential measurement error in the explanatory variables which could bias our results. Long differences removes some of the noise by averaging out temporary shocks [see Griliches and Hausman (1986)]. We also estimate equation (5) for a robustness check. The results are reported in the appendix in Tables A1 and A2.

The results for this specification are reported in Panel A of Tables 1 and 2. Again, note that we focus on the 14 manufacturing sectors in our analysis. However, we do report the results of estimating the model using data from all 35 sectors in tables A3 and A4 in the appendix. We also report the estimates for the control variables in the appendix in tables A5 and A6 to economise on presentation. Standard errors have been clustered at the country-sector level as a means to to deal with within group correlation of error terms.

The first two columns of Table 1 report the within-sector effects on the aggregate measures of GHG emission levels. The estimated coefficients in the production emission specification indicate that for developed countries a one percentage point increase in the growth of Chinese import penetration is associated with a 1.5 percent decrease in the growth of within-sector production-based emissions. In contrast, a 1 percentage point increase in the share of imports originating from China is associated with over a 2.5 percent increase in the growth of within-sector aggregate consumption-based emissions. Growth in the share of imports originating from China had a larger effect on each country's consumption-based emissions than on their productionbased emissions (in absolute values). The implication is that the increase in consumption emissions was not offset by the decrease in production emissions. The last two columns report the estimates for the intensity ratios. $^{12}$ These show that the increase in the growth of consumption-based emissions cannot be entirely explained by increasing consumption levels: Consumption also became more emissions intensive as the share of Chinese imports increased.

The first panel in table 2 reports results for the individual components of the aggregate measures. The

\footnotetext{
${ }^{12}$ The emission intensity of consumption is the ratio of consumption-based emissions to total imports plus domestic production of domestically consumed. The emission intensity of production is the ratio of production-based emissions to total exports plus domestic production of domestically consumed goods.
} 
first two columns examine the international trade components. Growth in the share of imports coming from China tended to increase the growth of a sector's imported emissions: A 1 percentage point increase in import penetration growth rates is associated with a 3.8 percent growth of emissions embodied in imported final goods. Higher Chinese import penetration also tended to increase the emission content of exports from developed countries. Increased trade with China tended to have a larger effect on the emission content of imports compared to exports. The large estimated effect on imported emissions suggests that the growth in emissions embodied in imports was a substantial contributor to the increase in consumption-based emissions thereby providing the necessary link between the growth in China's share of imports and the growth of consumption-based emissions.

Column three reports results for the GHG-import intensity ratio. Chinese liberalised trade had a positive and economically meaningful effect on the emission intensity of imports. Sectors that experienced larger growth in Chinese import penetration also experienced larger growth in the emission intensity of their imports. Again, the increase in emission levels was not only due to growth in consumption or imports: Consumption as well as imports grew more emissions intensive with growth in China's share of imports. The overall effect of a larger share of imports coming from China was a significant increase in the emission content of imports which contributed to the relatively larger effect on consumption-based emissions. There was no offsetting decrease in the emission content of exports from developed countries.

We investigate the emissions in domestically produced domestic final consumption goods in the last two columns. Column four reports the results for the level of emissions and column five reports the results for the emission intensity of domestic production. The estimate for the level of emissions is negative but statistically insignificant. Chinese import penetration as measured by the share of aggregate imports did not have a significant effect on the level of emissions embodied in the domestic production of domestic final consumption goods. However, growth in the emission intensity of these goods is positively associated with the growth in the share of imports coming from China; although the estimated effect is relatively small. These results suggest that domestic firms could be using more emission intensive intermediate goods, and because there was no significant effect on emission levels, there was likely a corresponding decrease in the amount of domestic production of final consumption goods, which offset the potential increase in emissions caused by the increase in emission intensities (see also section 3.2.3). Any potential reduction in domestic production emissions was likely offset by domestic firms using more emission intensive intermediate production goods.

These estimates taken together indicate that growth in the share of imports originating from China tended to increase the growth of consumption-based emissions and lower the growth of production-based emission. Moreover, the effect on consumption-based emissions was larger than on production-based emissions. The estimated effects for the individual components of the aggregate measures are consistent with the aggregate results and provide a link between the growth of Chinese imports and the growth of consumption-based 
emissions. The growth in emissions was due to growth in consumption (including imports) and consumption (and imports) becoming more emission intensive. The substantial growth in imported emission was not offset by changes in domestic emissions. There is some, albeit noisy, evidence that the emissions in the domestic production of domestically consumed goods declined (see also 3.2.3).

\subsubsection{Robustness Analysis: Including Sector Trends}

In this section we investigate the robustness of the results in section 3.2 .1 by addressing the possibility that an unobserved trend existed in sectors that experienced growth in their share of imports from China and would have experienced changes in emission even if China was not admitted to the WTO. For example, in figure 2, we observe an increase in the emission intensity of imports one year prior to China joining the WTO. This trend could be the result of firms in specific sectors anticipating entry or be due to some other unobserved factor. We attempt to control for potential cases of spurious correlation that may confound causation by estimating specifications with sector trends, $\Delta \kappa_{s}$ :

$$
\Delta Y_{i s t}=\beta_{1} \Delta M_{i s t}^{C H N}+\beta_{2} D_{i s t}^{d e v} \times \Delta M_{i s t}^{C H N}+\Delta x_{i s t}^{\prime} \gamma+\Delta \mu_{i t}+\Delta \kappa_{s}+\Delta \epsilon_{i s t} .
$$

Recall that the long-difference specification controls for country-sector specific trends. So, the model specified in equation 7 controls for country-year trends, country-sector trends and now sector trends. The results for this specification are reported in panel B of Tables 1 and 2. Controlling for unobserved sector specific trends tended to dampen the estimated magnitudes of the trade shock's effects on the various measures of emissions. However, the results are consistent with those reported in the panel A of both tables. Increased share of imports from China had a negative effect on the growth of production emissions and a positive effect on the growth of consumption emissions. The coefficient on consumption emissions suggests that a 1 percentage point increase in Chinese imports increased the growth of consumption emissions 1.4 percent and decreased production emissions by 1.1 percent. Larger growth in share of Chinese imports is associated with consumption and imports becoming more emission intensive. These results also confirm that the growth in imported emissions caused by a larger share of Chinese imports was not offset by a reduction in domestic emissions.

\subsubsection{Robustness Analysis: Alternative Measures of Trade Exposure - Scale Analysis}

The results reported in the first two panels in tables 1 and 2 used the China's share of each sectors' aggregate imports as a measure of import penetration. This measure summarises changes in the composition of each sector's imports and does not directly measure changes in the scale of Chinese imports relative to a sectors level of consumption or production. In this section we investigate the robustness of our results by estimating 
specifications based on changes in the scale of Chinese imports. Specifically, we use Chinese imports relative to each sectors consumption,

$$
M_{i s t}^{C H N, C}=\frac{I M P_{i s t}^{C H N}}{C_{i s t}},
$$

as well as relative to each sector's production,

$$
M_{i s t}^{C H N, D}=\frac{I M P_{i s t}^{C H N}}{D_{i s t}}
$$

The results are reported in the last two panels of Tables 1 and 2. The results reported in panel $\mathrm{C}$ are consistent with all the previous results. The main difference is the stronger effect on the level of emissions in domestically produced domestic final consumption goods. A one percentage point increase in Chinese imports relative to consumption decreases domestic emissions by almost 2 percent. The larger a sector's share of consumption is comprised of Chinese imports, the larger the decrease in the emissions from producing goods for final domestic consumption. Note that the emission intensity of domestic production is increasing in China's share of domestic consumption. This result is consistent with domestic consumption being substituted for imports (we investigate this further in section 3.3). ${ }^{13}$

The results reported in panel D are also consistent with the previous results. We do not observe the same effect on domestic emission that we observed in panel $\mathrm{C}$ because Chinese imports relative to production does not capture the substitution in consumption that the previous measure captures. However, the estimated effect on production emissions is larger relative to the alternative trade exposure specifications.

\subsubsection{Robustness Analysis: Difference-in-Difference Estimates}

In the previous two sections we investigated the robustness of the results by estimating different specifications of the same estimator. In this section, we investigate the robustness of our results and continue to investigate the causal relationship between liberalised trade and emissions by employing an estimator that relies on different identification arguments. Specifically, we use China's entry into the WTO as a quasi-natural experiment to estimate a difference-in-difference (DiD) estimator [See Aichele and Felbermayr (2015) for a similar treatment of the ratification of the Kyoto Protocol].

The main challenge for estimating a DiD estimator is establishing identification of the causal treatment effect. Our DiD identification strategy exploits the variation in import exposure across domestic sectors prior to China joining the WTO [see also Utar and Ruiz (2013), Han et al. (2012) and Bloom et al. (2016) for studies that used a similar identification strategy]. Variation in China's comparative advantage across sectors, prior to its entry into the WTO, means that not all domestic sectors were exposed to a substantial

\footnotetext{
${ }^{13}$ We estimated a regression equation equivalent to equation (7) with domestic consumption of domestically produced goods as the dependent variable. The estimate of $\beta_{1}$ suggests that a one percentage point increase in the share of imports from China decreased consumption by 1.7 percent. The $p$-value for the estimate is 0.053 .
} 


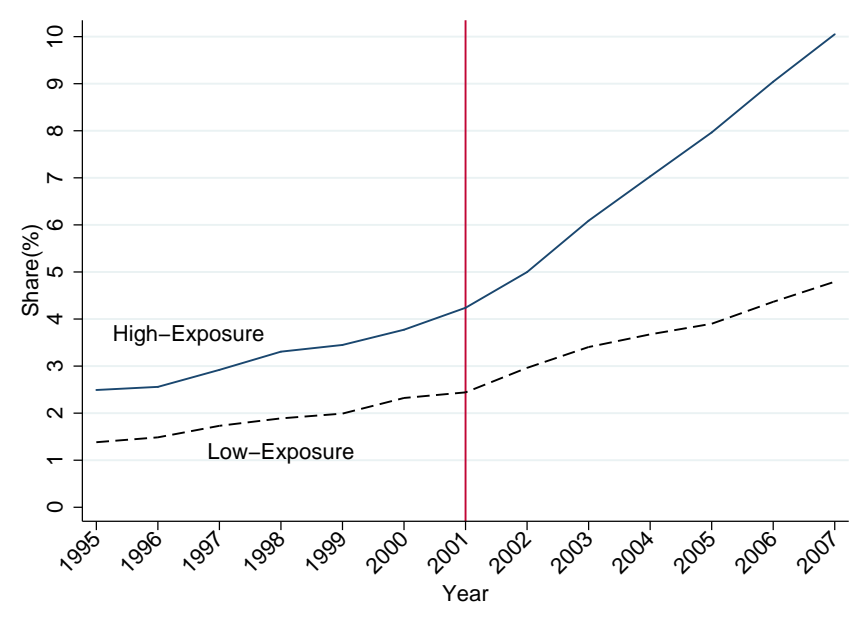

Figure 4: Share of Chinese Imports by Exposure Status

increase in Chinese imports after China was admitted to the WTO. Which sectors experienced the largest growth in Chinese exports depended on whether China had a comparative advantage in the sectors. The variation in exposure across sectors prior to China's admission to the WTO provides the means to identifying a control and a treatment group. The sectors with low import exposure prior to 1999 is the control group and the sectors with high import exposure prior to 1999 is the treatment group.

Identification requires that in the counterfactual case without China's admission to the WTO, conditional on various controls, the control group and the treatment group would have evolved identically over time. This counterfactual is not testable; however, examining the data can determine the reasonableness of the assumption. Figure 4 decomposes the average share of Chinese imports into high exposure sectors and low exposure sectors. High exposure sectors are those that were above the median import share in 1999. The sectors in which China was already exporting more strongly in 1999, two years before entry into the WTO, were the sectors that experienced a substantial increase in Chinese imports following the accession. ${ }^{14}$ The average annual growth of the share of Chinese imports for high exposure sectors in the six years post WTO, 2002-2007, was just under 12 percent, whereas the average annual growth for low exposure sectors was approximately eight percent. The annual growth rate for low exposure sectors before inclusion into the WTO was 8.5 percent, whereas the growth rate was seven percent for high exposure sectors. The annual growth rate for low exposure sectors was not significantly different from the growth rates of both low exposure and high exposure sectors before inclusion into the WTO. After inclusion into the WTO, growth rates of high exposure sectors increased substantially, whereas low exposure sectors did not.

A potential case of identification failure may occur if China's admission to the WTO was coincident with

\footnotetext{
${ }^{14}$ This is also confirmed by Amiti and Freund (2010) who show that over the 1997 to 2005 period at least three quarters of the aggregate growth of Chinese imports was from the expansion of existing products rather than from adding new products.
} 
another discontinuous shock that also affected GHG emissions in the importing countries. For example, some WTO countries ratified the Kyoto agreement around the same time that China entered the WTO (in 2002). Ratification of the agreement can be a concern if the effects of ratification on countries' emissions vary in the same timely pattern as China's preexisting comparative advantage. By including country-year fixed effects we attempt to control for unobserved country-specific effects that may be correlated with GHG emissions (Kyoto ratification, for example).

The DiD regression model in long-differences is

$$
\Delta Y_{i s t}=\beta_{1} D_{1999}^{C H N} \times \text { Post }_{t}+\beta_{2}\left(D_{i}^{d e v} \times D_{1999}^{C H N} \times \text { Post }_{t}\right)+\Delta x_{i s t}^{\prime} \gamma+\Delta \mu_{i t}+\Delta \epsilon_{i s t}
$$

where $D_{1999}^{C H N}$ is an indicator variable which equals one if the Chinese sector was a high import exposure sector in 1999 and Post $_{t}$ is a dummy variable equal to one in the post WTO-accession period. We think of 2002-07 as post-accession years, whereas 2001 is a transition year during which China's WTO-accession was only partially in effect for less than one month. The pre-2002 years provides a pretreatment specification period, though they could also capture possible anticipation effects.

The parameters of interest are $\beta_{1}$ and $\beta_{2}$, which measure the effect of China's liberalised trade on GHG emissions in those sectors with a stronger preexisting Chinese presence while controlling for appropriate fixed effects. We again look at aggregate GHG measures, presented in the first panel in Table 3, and their components, in the first panel of Table 4 . The results are all consistent with the results presented in Tables 1 and 2. Production emissions in developed countries decreased by 6.9 percent and consumption emissions increased by 16 percent in those sectors with high import exposure relative to sectors with low exposure. Once again, the increase in consumption emissions is greater than the decrease in production emissions. The estimated effects on imported emissions and on the emission intensity of imports is positive. The effect on domestic emissions in consumption goods was estimated to be negative but insignificant. The increase in imported emissions was not offset by a decrease in domestic emissions.

For a robustness check on the choice of treatment group, we employ a second $\mathrm{DiD}$ estimator that exploits the complete sample variation between domestic industries' predetermined 1999 Chinese imports exposure together with the temporal variation before and after China's admission to the WTO. In this specification, the long difference regression is

$$
\Delta Y_{i s t}=\beta_{1} M_{s 1999}^{C H N} \times \text { Post }_{t}+\beta_{2}\left(D_{i}^{d e v} \times M_{s 1999}^{C H N} \times \text { Post }_{t}\right)+\Delta x_{i s t}^{\prime} \gamma+\Delta \mu_{i t}+\Delta \epsilon_{i s t}
$$

where $M_{s 1999}^{C H N}$ is a measure of the share of Chinese imports in the aggregate imports in industry $s$ across all other countries. In this specification, we do not rely on assigning sectors based on the median import shares rather we use actual import shares in each sector. The results are reported in panel B of Tables 3 and 4 . The 
estimated direction of the effects on the various measures of emissions are consistent with those reported for the first DiD specification as well as with those reported in the previous tables. The effect on production emissions is negative, whereas the effect on consumption emissions is positive. Again, the effect on domestic emissions was estimated to be negative but insignificant. Imported emissions and emission intensity were estimated to be positively affected by liberalised Chinese trade.

The consistent set of results using two different estimators based on different identification arguments, using various specifications, indicate that liberalised trade with China had a significant effect on emissions in developed countries. Increased trade with China increased the growth of Consumption-based emissions. The increase in consumption-based emissions was due to an increase the growth of consumption combined with an increase in emission intensities. The link between the growth of Chinese trade and the growth of consumption emissions was through the increase in the emissions embodied in imports. The results also confirm that the increase in imported emissions was not offset by reduced domestic emissions. The increase in consumption emissions was estimated to be larger than the decrease in production emissions.

\subsubsection{Robustness Analysis: Controlling for Endogeneity}

We continue to investigate the robustness of the results using another estimator with a different identification argument. A possible issue with the OLS estimation of equation (5) is the potential endogeneity of Chinese imports. Endogeneity is a concern if there were unobserved country-sector specific shocks that affected the various measures of emissions and were correlated with Chinese import penetration at the country-sector level. For example, exogenous changes in domestic emission policies or changes in regulations may have changed relative prices thereby increasing the demand for Chinese imports. The OLS estimates of the effect of Chinese liberalised trade on GHG emissions could be biased if exogenous domestic policy shocks led to more Chinese imports and larger imported emissions. To address this concern, we construct an instrumental variables (IV) estimator based on the exogenous intensification of Chinese imports after joining the WTO in 2001 jointly with a measure of China's comparative advantage. [see Bloom et al. (2016)].

Growth of China's aggregate exports must be exogenous from the perspective of the individual sectors in each of the importing countries. Growth of aggregate Chinese exports was likely driven by exogenous (from the perspective of each sector in the importing countries) Chinese trade liberalization policy. In addition, the initial variation in each sector's exposure to Chinese imports in 1999, two years before the accession, was largely determined by Chinese comparative advantage. In fact, the sectors that experienced the most growth were those in which China had a comparative advantage [again, see Amiti and Freund (2010) for details concerning Chinese export growth]. By interacting the growth of aggregate Chinese imports with Chinese import shares in each sector before China's WTO accession, we get cross-sector variation in the degree of Chinese comparative advantage. 
We use sector import penetration in 1999 interacted with the overall growth of aggregate Chinese imports as an instrument for country-sector Chinese import penetration. The first-stage regression for the IV estimator is:

$$
\Delta M_{i s t}^{C H N}=\pi_{0}+\pi_{1} M_{s, 1999}^{C H N} \times \Delta X_{t}^{C H N}+\Delta \mu_{i t}+\Delta \epsilon_{i s t}
$$

where $M_{s, 1999}^{C H N}$ is a measure of Chinese import penetration of each sector in 1999 (note that it is not indexed by country) and $\Delta X_{t}^{C H N}$ is Chinese export growth. We also estimated equation (12) using two alternative instruments: we used sector import penetration in 1998 as well as in 1997 interacted with aggregate growth of Chinese imports. The results are similar.

The results of the IV regression of equation (5) for developed countries is reported in panel A of Tables 5 and 6 , and in panel B, we report the results for all 39 countries in the sample. The first stage F-statistic is also reported for each specification. The first stage is strong in all specifications indicating that the instrument is relevant. The IV estimator generated similar quantitative results as the OLS estimator. Note that the estimated effects tended to be larger than the OLS estimates. In particular, the effect on emissions in domestically produced final consumption goods in developed countries is negative and statistically significant: A percentage point increase in the proportion of imports originating from China results in a 4.3 percent decrease in domestically produced consumption emissions. The main conclusions from all the previous estimates are supported.

\subsection{Offshoring GHG Emissions}

Our analysis thus far established that sectors with increased exposure to Chinese imports experienced declining production-based emission and increasing consumption-based emission. One factor driving these results was imports becoming more emission intensive as trade with China continued to grow. Moreover, there is some statistical evidence that increased imports from China reduced the emissions from domestically produced final consumption goods consumed in the domestic market. In particular, the results reported in panel $\mathrm{C}$ of table 2 indicate that when the imports from China increase relative to the sector's consumption then domestically produced emissions decline. These effects on traded emissions and on domestic produced consumption emissions raises questions concerning offshoring.

Offshoring involves the extent that countries respond to changes in the relative costs of domestic and foreign production of emission intensive intermediate goods by outsourcing the production of these intermediate goods to foreign countries [see Levinson (2010) and Levinson (2009)]. One concern is the pollution haven effect: Implementing stringent environmental policy increases the relative costs of producing emission intensive goods causing production to be relocated to countries with less environmental regulation [see Levinson and Taylor (2008)]. A related concern is carbon leakage [see Aichele and Felbermayr (2015)]. Even in the 
absence of changes to environmental policy, issues concerning offshoring emissions can arise from international trade agreements and other trade policies that change relative costs and alter comparative advantage. Changes in international trade flows simultaneously alter the emissions embodied in international trade.

Offshoring emission intensive production in response to changes in relative costs is an important policy issue because it has the potential to mitigate environmental objectives of domestic policy. We investigate the possibility that offshoring domestic intermediate production by manufacturing sectors to China contributed to the increase in the growth of imported emissions and the reduction in domestically produced consumption emissions. We proceed in two steps. We first construct measures of offshoring and use them to determine if offshoring intermediate production to China increased after China was admitted to the WTO. Second, if the rate of offshoring increased, then we want to know how much of the observed changes in GHG emissions were due to offshoring intermediate production to China.

We use two measures of offshoring by each sector-country pair. Following Feenstra and Hanson (1999), we compute a narrow and broad measure of offshoring. The broad measure of offshoring by sector $s$ in country $i$, denoted by $O_{i s t}^{B}$, is the ratio of the sum of imported intermediate inputs from all 14 manufacturing sectors in China to total intermediate inputs by sector $s$ in country $i$. The difference between Chinese import penetration, $M_{i s t}^{C H N}$, and the broad measure of offshoring, besides being normalised by different denominator, is that import penetration includes all imports from one sector in China to the same domestic importing sector, whereas the broad measure of offshoring is based on imports of intermediate goods from all 14 manufacturing sectors in China to one domestic importing sector.

The narrow measure (within-sector offshoring), denoted by $O_{i s t}^{N}$ is computed as the ratio of intermediate inputs imported from sector $s$ in China to the total intermediate inputs used by sector $s$ in country $i$. The narrow measure differs from the broad measure in that the narrow measure restricts the measure to include only the intermediate inputs from the same foreign sector. The idea behind the narrow measure is it measures the intermediate inputs that were imported from China that could have been produced by the domestic sector since the imports come from the same sector [see Feenstra and Hanson (1999)]. For example, a domestic firm that produces electronic equipment (cell phones) could be considered to be offshoring production if it imports electronic parts (circuit boards, for example) rather than producing the intermediate goods domestically.

In figure 5, we report the annual means (over all sectors and countries) of both measures of offshoring. Changes in offshoring growth rates mimics China's export trade growth illustrated in figure 1. Annual offshoring growth rates increased by 3 percentage points after China was admitted to the WTO: average annual growth rates were around 12 percent prior to 2001, and approximately 15 percent after 2001. Offshoring intermediate inputs to China increased over time with growth rates increasing after 2001.

We estimate equation 6 with the response variable being the two measures of offshoring and report the results on panel A in Table 7. We also estimate a DiD model under the same identification arguments as 


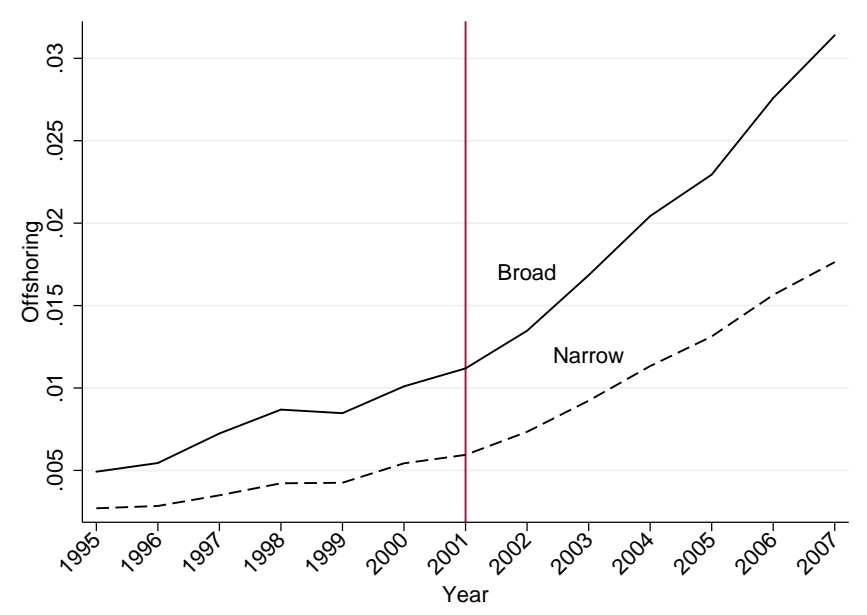

Figure 5: Broad and Narrow Measures of Offshoring

models (10) and (11). The results are reported in panels B and C in Table 7. The results for both estimators and for each of the measures indicate a significant increase in offshoring growth after China was admitted into the WTO. Figure 5 and the results presented in Table 7 suggest the rate at which sectors in different countries offshored production to China increased after China joined the WTO. The question now is how much of the increase in consumption emissions and imported emissions was due to offshoring?

Turning to the second step, we would like to know how growth in offshoring after China was admitted into the WTO affected GHG emissions. We decompose trade into three parts: narrow and broad offshoring as well as import penetration net of offshoring, and estimate a series of regression models. Each regression model is specified as

$$
\begin{aligned}
\Delta Y_{i s t}=\beta_{1} \Delta \tilde{M}_{i s t}^{C H N}+\beta_{2} \Delta \tilde{O}_{i s t}^{B}+\beta_{3} \Delta O_{i s t}^{N} & +\beta_{4} \Delta\left(D_{i s t}^{d e v} \times \tilde{M}_{i s t}^{C H N}\right) \\
& +\left(D_{i s t}^{d e v} \times \tilde{O}_{i s t}^{B}\right)+\beta_{6} \Delta\left(D_{i s t}^{d e v} \times O_{i s t}^{N}\right)+\Delta \mu_{i t}+\Delta x_{i s t}^{\prime} \gamma+\epsilon_{i s t}
\end{aligned}
$$

were $Y_{\text {ist }}$ denotes the various measures of emissions. Note that the numerator of the import penetration measure, $I M P_{i s t}^{C H N}$ includes the numerator of the narrow measure of offshoring since $I M P_{i s t}^{C H N}$ includes trade in intermediate goods. Therefore, in this regression analysis we use an adjusted measure of import penetration: The adjusted measure, $\tilde{M}_{i s t}^{C H N}$, does not include intermediate exports from sector $s$ in China to sector $s$ in the importing country. We also use an adjusted broad measure of offshoring by taking out narrow offshoring.

The results of the regressions are reported in table 8. Higher offshoring growth rates to China (both measures) corresponded to a decrease in production-based emissions and an increase in consumption-based 
emissions. Within-sector offshoring, $O_{i s t}^{N}$, was estimated to have the strongest effect on production and consumption emissions. Recall that the idea behind $O_{i s t}^{N}$ is it measures the intermediate inputs that were imported from China that could have been produced by the domestic sector.

Larger rates of within-sector offshoring led to growth in consumption-based emissions implying that changes in internationally traded emissions are likely important. Indeed, results presented in column four show that larger rates of within-sector offshoring led to importing more emissions. Moreover, growth in within-sector offshoring tended to have the largest effect on emission intensity growth rates. The estimated effect of offshoring on the emission intensity of domestic production was negative but only the broad measure of offshoring was statistically insignificant.

These results, together with the previous ones, provide some statistical evidence that changes in relative costs via decreasing transaction costs and/or eliminating trade barriers had important implications for traded emissions. Liberalised trade with China had important effects on GHG emissions. The results concerning offshoring suggest that one determinant of changes in GHG emissions was within-sector offshoring: The increase of within-sector offshoring growth to China caused consumption emissions growth rates to increase via larger import emission intensity growth rates.

\section{Conclusion}

Our goal in this paper was to empirically investigate the effects of a trade liberalising event on a global externality. Specifically, we analysed the effects of China's liberalised trade on GHG emissions of its trading partners since its entry into the WTO. This research contributes to the existing literature on the links between trade policy and environmental outcomes as well as between environmental policy and international trade. Research into these linkages has focused on the pollution haven hypothesis and more recently on carbon leakage; however, trade policy can also affect traded emissions by changing relative costs and altering comparative advantage. In both cases, international trade has the potential to mitigate environmental objects.

Our empirical results support the idea that liberalising trade with China has had a significant economic effect on GHG emissions. Using data from the World Input-Output Database, we constructed two aggregate measures of GHG emissions as well as measures of the GHG emissions embodied in international trade and domestic production. Our estimates show that an increase in the growth rate of Chinese import penetration corresponded to a decrease in the growth of production emissions and an increase in the growth rate of consumption emissions in China's trading partners. The contrasting results between production and consumption emissions are explained by the emissions embodied in the imports of China's trading partners. Increases in the growth of Chinese import penetration rates corresponded to an increase in the growth in 
the amount of imported emissions as well as in the emission intensity of imports. The decrease in domestically produced consumption emissions was not large enough to offset the increase in imported emissions. Our results or robust to alternative specifications as well as to alternative estimators that rely of different identification assumptions.

In terms of policy, our results provides additional evidence that trade policy can have important implications for traded GHG emissions. Of course, this issue has long been recognized and, in fact, has lead to a research agenda studying whether trade negotiations and agreements should include environmental policy. Our results show that a significant change in trade policy in one country can have global environmental consequences. Moreover, our results also have a more modest implication: tracking both production-based and consumption-based emissions provides a more complete account of emissions associated with macroeconomic activity. Given that GHG emissions are a global externality (emissions are transboundary) and that most climate agreements and policy are incomplete, in the sense that they do not include all emitters of GHG emissions, computing both measures of emissions provides the opportunity to track potential concerns with trade policy affecting traded emissions and potentially mitigating environmental objectives as well as GHG regulation influencing traded emissions (pollution haven hypothesis and leakage) thereby mitigating environmental objectives. 


\section{References}

Aichele, R. and G. Felbermayr (2015): "Kyoto and Carbon Leakage: An Empirical Analysis of the Carbon Content of Bilateral Trade," The Review of Economics and Statistics, 97, 104-115.

Amiti, M. And C. Freund (2010): "The Anatomy of China's Export Growth," in China's Growing Role in World Trade, ed. by R. C. Feenstra and S.-J. Wei, University of Chicago Press, 35-56.

Andersen, T. B., M. Barslund, C. W. Hansen, T. Harr, and P. S. Jensen (2014): "How Much Did China's WTO Accession Increase Economic Growth in Resource-Rich Countries?" China Economic Review, 30, $16-26$.

Autor, D. H., D. Dorn, And G. H. Hanson (2013): "The China Syndrome: Local Labor Market Effects of Import Competition in the United States," American Economic Review, 103, 2121-68.

Bernard, A. B., J. B. Jensen, And P. K. Schott (2006): "Survival of the best fit: Exposure to low-wage countries and the (uneven) growth of U.S. manufacturing plants," Journal of International Economics, $68,219-237$.

Bloom, N., M. Draca, and J. V. Reenen (2016): "Trade Induced Technical Change: The Impact of Chinese Imports on Innovation, Diffusion and Productivity," Review of Economic Studies, 83, 87-117.

Copeland, B. R. and M. S. Taylor (2005): "Free Trade and Global Warming: A Trade Theory View of The Kyoto Protocol," Journal of Environmental Economics and Management, 49, 205 - 234.

Davis, S. J. And K. Caldeira (2010): "Consumption-Based Accounting of CO2 Emissions," Proceedings of the National Academy of Sciences, 107, 5687-5692.

Dietzenbacher, E., B. Los, R. Stehrer, M. Timmer, and G. De Vries (2013): "The Construction of World Input-Output Tables in the WIOD Project," Economic Systems Research, 25, 71-98.

Duan, Y. And X. Jiang (2017): "Temporal Change of China's Pollution Terms of Trade and its Determinants," Ecological Economics, 132, $31-44$.

Feenstra, R. C. And G. H. Hanson (1999): "The Impact of Outsourcing and High-Technology Capital on Wages: Estimates For the United States, 1979-1990," The Quarterly Journal of Economics, 114, 907-940.

Frankel, J. A. And A. K. Rose (2005): "Is Trade Good or Bad for the Environment? Sorting Out the Causality," The Review of Economics and Statistics, 87, 85-91.

Griliches, Z. And J. A. Hausman (1986): "Errors in Variables in Panel Data," Journal of Econometrics, 31, 93 - 118. 
Han, J., R. LiU, AND J. Zhang (2012): "Globalization and wage inequality: Evidence from urban China," Journal of International Economics, 87, 288 - 297.

Levinson, A. (2009): "Technology, International Trade, and Pollution from US Manufacturing," American Economic Review, 99, 2177-92.

(2010): “Offshoring Pollution: Is the United States Increasingly Importing Polluting Goods?" Review of Environmental Economics and Policy, 4, 63-83.

Levinson, A. And M. S. TAYlor (2008): "Unmasking the Pollution Haven Effect," International Economic Review, 49, 223-254.

Levitt, C., M. S. Pedersen, And A. Sørensen (2015): "Examining the Efforts of a Small, Open Economy to Reduce Carbon Emissions: The Case of Denmark," Ecological Economics, 119, 94-106.

Moran, D. ANd R. Wood (2014): “Covergence between the EORA, WIOD, EXIOBASE, AND OPENEU'S Consumption-Based Carbon Accounts," Economic Systems Research, 26, 245-261.

Peters, G. P., J. C. Minx, C. L. Weber, And O. Edenhofer (2011): "Growth in emission transfers via international trade from 1990 to 2008," Proceedings of the National Academy of Sciences, 108, 8903-8908.

Timmer, M. P., E. Dietzenbacher, B. Los, R. Stehrer, and G. J. de Vries (2015): "An Illustrated User Guide to the World InputOutput Database: the Case of Global Automotive Production," Review of International Economics, 23, 575 - 605 .

Utar, H. And L. B. T. Ruiz (2013): "International Competition and Industrial Evolution: Evidence From The Impact of Chinese Competition on Mexican Maquiladoras," Journal of Development Economics, 105, $267-287$.

Vennemo, H., K. Aunan, J. He, T. Hu, S. Li, and K. Rypdal (2008): "Environmental Impacts of China's WTO-Accession," Ecological Economics, 64, 893 - 911.

Wiedmann, T. (2009): "A Review of Recent Multi-Region Input-Output Models Used for ConsumptionBased Emission and Resource Accounting," Ecological Economics, 69, 211 - 222.

Wiedmann, T., M. Lenzen, K. Turner, And J. Barrett (2007): "Examining the Global Environmental Impact of Regional Consumption Activities-Part 2: Review of Input-Output Models for the Assessment of Environmental Impacts Embodied in Trade," Ecological Economics, 61, 15 - 26.

Xu, Y. And E. Dietzenbacher (2014): "A Structural Decomposition Analysis Of The Emissions Embodied In Trade," Ecological Economics, 101, 10 - 20. 
Table 1: OLS Results, Aggregate Measures (Long-Differences)

\begin{tabular}{|c|c|c|c|c|}
\hline & $\begin{array}{c}\text { Prod. GHG } \\
\ln \left(G H G^{p}\right)\end{array}$ & $\begin{array}{l}\text { Cons. GHG } \\
\ln \left(G H G^{c}\right)\end{array}$ & $\begin{array}{l}\text { GHG-Production } \\
\text { Intensity Ratio }\end{array}$ & $\begin{array}{l}\text { GHG-Consumption } \\
\text { Intensity Ratio }\end{array}$ \\
\hline \multicolumn{5}{|c|}{ Panel A: China's Import Share (OLS) } \\
\hline$M^{C H N}$ & $\begin{array}{c}-0.014^{* *} \\
(0.006)\end{array}$ & $\begin{array}{c}0.027^{* * *} \\
(0.005)\end{array}$ & $\begin{array}{c}-0.015^{* *} \\
(0.007)\end{array}$ & $\begin{array}{c}0.025^{* * *} \\
(0.006)\end{array}$ \\
\hline$M^{C H N} \times D I$ & $\begin{array}{c}0.006 \\
(0.007)\end{array}$ & $\begin{array}{c}-0.014^{*} \\
(0.008)\end{array}$ & $\begin{array}{c}0 \\
(0.008)\end{array}$ & $\begin{array}{l}-0.012 \\
(0.008)\end{array}$ \\
\hline$R^{2}$ & 0.32 & 0.36 & 0.46 & 0.55 \\
\hline Country $\times$ Year FE & Yes & Yes & Yes & Yes \\
\hline Full Set of Controls & Yes & Yes & Yes & Yes \\
\hline Observations & 1060 & 1075 & 1060 & 1075 \\
\hline \multicolumn{5}{|c|}{ Panel B: Including Sector Trends (OLS) } \\
\hline$M^{C H N}$ & $\begin{array}{c}-0.011^{*} \\
(0.006)\end{array}$ & $\begin{array}{c}0.014^{* * *} \\
(0.005)\end{array}$ & $\begin{array}{l}-0.015^{* *} \\
(0.007)\end{array}$ & $\begin{array}{l}0.012^{* *} \\
(0.006)\end{array}$ \\
\hline$M^{C H N} \times D I$ & $\begin{array}{c}0.003 \\
(0.007)\end{array}$ & $\begin{array}{l}-0.004 \\
(0.006)\end{array}$ & $\begin{array}{c}0 \\
(0.009)\end{array}$ & $\begin{array}{l}-0.002 \\
(0.007)\end{array}$ \\
\hline$R^{2}$ & 0.34 & 0.40 & 0.47 & 0.59 \\
\hline Country $\times$ Year FE & Yes & Yes & Yes & Yes \\
\hline Sector Trends & Yes & Yes & Yes & Yes \\
\hline Full Set of Controls & Yes & Yes & Yes & Yes \\
\hline Observations & 1060 & 1075 & 1060 & 1075 \\
\hline \multicolumn{5}{|c|}{ Panel C: Share of Consumption } \\
\hline$M^{C H N, C}$ & $\begin{array}{l}-0.003 \\
(0.003)\end{array}$ & $\begin{array}{c}0.019^{* *} \\
(0.01)\end{array}$ & $\begin{array}{c}-0.046^{* *} \\
(0.01)\end{array}$ & $\begin{array}{c}0.002 \\
(0.004)\end{array}$ \\
\hline$M^{C H N, C} \times D I$ & $\begin{array}{l}-0.012 \\
(0.019)\end{array}$ & $\begin{array}{c}0.010 \\
(0.027)\end{array}$ & $\begin{array}{c}0.011 \\
(0.032)\end{array}$ & $\begin{array}{l}0.026 \\
(0.02)\end{array}$ \\
\hline$R^{2}$ & 0.33 & 0.39 & 0.47 & 0.58 \\
\hline Country $\times$ Year FE & Yes & Yes & Yes & Yes \\
\hline Sector Trends & Yes & Yes & Yes & Yes \\
\hline Full set of Controls & Yes & Yes & Yes & Yes \\
\hline Observations & 1060 & 1075 & 1060 & 1075 \\
\hline \multicolumn{5}{|c|}{ Panel D: Share of Production } \\
\hline$M^{C H N, P}$ & $\begin{array}{c}-0.015^{* *} \\
(0.003)\end{array}$ & $\begin{array}{c}0.054^{* * *} \\
(0.018)\end{array}$ & $\begin{array}{c}-0.035^{*} \\
(0.021)\end{array}$ & $\begin{array}{c}0.022 \\
(0.018)\end{array}$ \\
\hline$M^{C H N, P} \times D I$ & $\begin{array}{c}0.006 \\
(0.027)\end{array}$ & $\begin{array}{c}0.003 \\
(0.034)\end{array}$ & $\begin{array}{l}0.021 \\
(0.04)\end{array}$ & $\begin{array}{c}0.014 \\
(0.025)\end{array}$ \\
\hline$R^{2}$ & 0.33 & 0.40 & 0.46 & 0.59 \\
\hline Country $\times$ Year FE & Yes & Yes & Yes & Yes \\
\hline Sector Trends & Yes & Yes & Yes & Yes \\
\hline Full Set of Controls & Yes & Yes & Yes & Yes \\
\hline Observations & 1060 & 1075 & 1060 & 1075 \\
\hline
\end{tabular}

1. Note that all variables are in long-differences. We employ a slight abuse of notation by omitting the $\Delta$ notation to avoid clutter. $\quad 2 .^{* * *},{ }^{* *},{ }^{*}$ denotes estimates statistically significant at the 1,5 or 10 percent level.

3. Robust standard errors are reported in parentheses. The standard errors have been clustered at the countryindustry level to account for within group correlation. 4. The variation in the number of observations is due to non-positive emissions reported in some industries for different countries. 
Table 2: OLS Results, Component Measures (Long-Differences)

\begin{tabular}{|c|c|c|c|c|c|}
\hline & $\begin{array}{c}\text { Export GHG } \\
\ln \left(G H G^{x}\right)\end{array}$ & $\begin{array}{l}\text { Import GHG } \\
\ln \left(G H G^{m}\right)\end{array}$ & $\begin{array}{l}\text { GHG-Import } \\
\text { Intensity Ratio }\end{array}$ & $\begin{array}{l}\text { Domestic } \\
\ln \left(G H G^{d}\right)\end{array}$ & $\begin{array}{c}\text { Dom. Intensity } \\
\text { Ratio }\end{array}$ \\
\hline \multicolumn{6}{|c|}{ Panel A: China's Import Share (OLS) } \\
\hline$M^{C H N}$ & $\begin{array}{c}0.011^{* *} \\
(0.005)\end{array}$ & $\begin{array}{c}0.038^{* * *} \\
(0.005)\end{array}$ & $\begin{array}{c}0.036^{* * *} \\
(0.009)\end{array}$ & $\begin{array}{l}-0.011 \\
(0.010)\end{array}$ & $\begin{array}{c}0.006^{* * *} \\
(0.002)\end{array}$ \\
\hline$M^{C H N} \times D I$ & $\begin{array}{l}-0.012 \\
(0.008)\end{array}$ & $\begin{array}{l}-0.002 \\
(0.008)\end{array}$ & $\begin{array}{c}0.003 \\
(0.011)\end{array}$ & $\begin{array}{c}0.001 \\
(0.018)\end{array}$ & $\begin{array}{c}-0.012^{* *} \\
(0.006)\end{array}$ \\
\hline$R^{2}$ & 0.44 & 0.38 & 0.55 & 0.24 & 0.55 \\
\hline Country $\times$ Year FE & Yes & Yes & Yes & Yes & Yes \\
\hline Full Set of Controls & Yes & Yes & Yes & Yes & Yes \\
\hline Observations & 1067 & 1081 & 1081 & 1049 & 1079 \\
\hline \multicolumn{6}{|c|}{ Panel B: Including Sector Trends (OLS) } \\
\hline$M^{C H N}$ & $\begin{array}{l}0.011^{* *} \\
(0.005)\end{array}$ & $\begin{array}{c}0.024^{* * *} \\
(0.006)\end{array}$ & $\begin{array}{l}0.026^{* *} \\
(0.011)\end{array}$ & $\begin{array}{l}-0.001 \\
(0.012)\end{array}$ & $\begin{array}{c}0.005^{* *} \\
(0.002)\end{array}$ \\
\hline$M^{C H N} \times D I$ & $\begin{array}{l}-0.012 \\
(0.008)\end{array}$ & $\begin{array}{c}0.008 \\
(0.0007)\end{array}$ & $\begin{array}{c}0.010 \\
(0.013)\end{array}$ & $\begin{array}{l}-0.005 \\
(0.018)\end{array}$ & $\begin{array}{c}-0.011^{* *} \\
(0.005)\end{array}$ \\
\hline$R^{2}$ & 0.44 & 0.54 & 0.58 & 0.27 & 0.57 \\
\hline Country $\times$ Year FE & Yes & Yes & Yes & Yes & Yes \\
\hline Sector Trends & Yes & Yes & Yes & Yes & Yes \\
\hline Full Set of Controls & Yes & Yes & Yes & Yes & Yes \\
\hline Observations & 1067 & 1081 & 1081 & 1049 & 1079 \\
\hline \multicolumn{6}{|c|}{ Panel C: Share of Consumption } \\
\hline$M^{C H N, C}$ & $\begin{array}{c}0.011^{* *} \\
(0.04)\end{array}$ & $\begin{array}{c}0.013^{* * *} \\
(0.002)\end{array}$ & $\begin{array}{c}0.019^{* * *} \\
(0.002)\end{array}$ & $\begin{array}{c}-0.019^{* * *} \\
(0.005)\end{array}$ & $\begin{array}{c}0.003^{* * *} \\
(0.001)\end{array}$ \\
\hline$M^{C H N, C} \times D I$ & $\begin{array}{c}0.024 \\
(0.018)\end{array}$ & $\begin{array}{l}0.051 \\
(0.04)\end{array}$ & $\begin{array}{l}0.027 \\
(0.04)\end{array}$ & $\begin{array}{c}0.073 \\
(0.051)\end{array}$ & $\begin{array}{c}0.001 \\
(0.020)\end{array}$ \\
\hline$R^{2}$ & 0.48 & 0.51 & 0.56 & 0.28 & 0.57 \\
\hline Country $\times$ Year FE & Yes & Yes & Yes & Yes & Yes \\
\hline Sector Trends & Yes & Yes & Yes & Yes & Yes \\
\hline Full set of Controls & Yes & Yes & Yes & Yes & Yes \\
\hline Observations & 1067 & 1081 & 1081 & 1049 & 1079 \\
\hline \multicolumn{6}{|c|}{ Panel D: Share of Production } \\
\hline$M^{C H N, P}$ & $\begin{array}{c}0.063^{* * *} \\
(0.016)\end{array}$ & $\begin{array}{c}0.067^{* * *} \\
(0.022)\end{array}$ & $\begin{array}{c}0.035 \\
(0.031)\end{array}$ & $\begin{array}{l}-0.008 \\
(0.042)\end{array}$ & $\begin{array}{c}0.038^{* * *} \\
(0.011)\end{array}$ \\
\hline$M^{C H N, P} \times D I$ & $\begin{array}{l}-0.028 \\
(0.027)\end{array}$ & $\begin{array}{c}0.005 \\
(0.047)\end{array}$ & $\begin{array}{c}0.015 \\
(0.043)\end{array}$ & $\begin{array}{c}0.017 \\
(0.071)\end{array}$ & $\begin{array}{l}-0.012 \\
(0.020)\end{array}$ \\
\hline$R^{2}$ & 0.48 & 0.51 & 0.55 & 0.27 & 0.57 \\
\hline Country $\times$ Year FE & Yes & Yes & Yes & Yes & Yes \\
\hline Sector Trends & Yes & Yes & Yes & Yes & Yes \\
\hline Full Set of Controls & Yes & Yes & Yes & Yes & Yes \\
\hline Observations & 1067 & 1081 & 1081 & 1049 & 1079 \\
\hline
\end{tabular}

1. Note that all variables are in long-differences. We employ a slight abuse of notation by omitting the $\Delta$ notation to avoid clutter. $\quad 2 .{ }^{* * *},{ }^{* *},{ }^{*}$ denotes estimates statistically significant at the 1,5 or 10 percent level.

3. Robust standard errors are reported in parentheses. The standard errors have been clustered at the country-industry level to account for within group correlation. 4. The variation in the number of observations is due to non-positive emissions reported in some industries for different countries. 
Table 3: DiD Results, Aggregate Measures (Long-Differences)

\begin{tabular}{lcccc}
\hline & $\begin{array}{c}\text { Prod. GHG } \\
\ln \left(G H G^{p}\right)\end{array}$ & $\begin{array}{c}\text { Cons. GHG } \\
\ln \left(G H G^{c}\right)\end{array}$ & $\begin{array}{c}\text { GHG-Production } \\
\text { Intensity Ratio }\end{array}$ & $\begin{array}{c}\text { GHG-Consumption } \\
\text { Intensity Ratio }\end{array}$ \\
\hline Panel A: DiD - Median Shares & & & & \\
$D^{C H N}$ & $-0.069^{* *}$ & $0.16^{* * *}$ & 0.006 & $0.177^{* * *}$ \\
& $(0.034)$ & $(0.032)$ & $(0.045)$ & $(0.029)$ \\
$D^{C H N} \times D I$ & 0.003 & $0.015^{* *}$ & -0.003 & 0.005 \\
$R^{2}$ & $(0.007)$ & $(0.007)$ & $(0.008)$ & $(0.004)$ \\
Country $\times$ Year FE & 0.32 & 0.36 & 0.45 & 0.54 \\
Observations & Yes & Yes & Yes & Yes \\
\hline Panel B DiD - Full Shares & 1060 & 1075 & 1060 & 1075 \\
\hline$M_{s}^{C H N}$ & & & & \\
$M^{C H N} \times D I$ & $-0.040^{* * *}$ & $0.047^{* * *}$ & -0.029 & $0.059^{* * *}$ \\
$R^{2}$ & $(0.009)$ & $(0.009)$ & $(0.011)$ & $0.010)$ \\
Country $\times$ Year FE & $0.002^{*}$ & 0.002 & -0.001 & 0 \\
Full Set of Controls & $(0.001)$ & $(0.002)$ & $(0.001)$ & $(0.001)$ \\
Observations & 0.32 & 0.36 & 0.45 & 0.54 \\
\hline & Yes & Yes & Yes & Yes \\
1. Yes & 1060 & 1075 & 1060 & Yes \\
\hline
\end{tabular}

1. Note that all variables are in long-differences. We employ a slight abuse of notation by omitting the $\Delta$ notation to avoid clutter. $\quad 2 .{ }^{* * *},{ }^{* *},{ }^{*}$ denotes estimates statistically significant at the 1,5 or 10 percent level. 3. Robust standard errors are reported in parentheses. The standard errors have been clustered at the country-industry level to account for within group correlation. 4. The variation in the number of observations is due to non-positive emissions reported in some industries for different countries.

Table 4: DiD Results, Component Measures (Long-Differences)

\begin{tabular}{lccccc}
\hline & $\begin{array}{c}\text { Export GHG } \\
\ln \left(G H G^{*}\right)\end{array}$ & $\begin{array}{c}\text { Import GHG } \\
\ln \left(G H G^{m}\right)\end{array}$ & $\begin{array}{c}\text { GHG-Import } \\
\text { Intensity Ratio }\end{array}$ & $\begin{array}{c}\text { Domestic } \\
\ln \left(G H G^{d}\right)\end{array}$ & $\begin{array}{c}\text { Dom. Intensity } \\
\text { Ratio }\end{array}$ \\
\hline Panel A: DiD - Median Shares & & & & & \\
D & $-0.075^{*}$ & $0.191^{* * *}$ & $0.624^{* * *}$ & -0.087 & 0.007 \\
& $(0.04)$ & $(0.032)$ & $(0.113)$ & $(0.06)$ & $(0.017)$ \\
$D^{C H N} \times D I$ & -0.003 & $0.031^{* * *}$ & 0.025 & 0.018 & 0.006 \\
$R^{2}$ & $(0.009)$ & $(0.009)$ & $(0.020)$ & $(0.015)$ & $(0.003)$ \\
Country $\times$ Year FE & 0.44 & 0.45 & 0.34 & 0.25 & 0.55 \\
Observations & Yes & Yes & Yes & Yes & Yes \\
\hline Panel B: DiD - Full Shares & 1067 & 1081 & 1081 & 1049 & 1079 \\
\hline$M_{s}^{C H N}$ & & & & -0.018 & -0.002 \\
$M^{C H N} \times D I$ & -0.017 & $0.035^{* * *}$ & $0.19^{* * *}$ & $(0.021)$ & $(0.005)$ \\
$R^{2}$ & $(0.011)$ & $(0.010)$ & $(0.035)$ & $0.005^{* *}$ & 0.001 \\
Country $\times$ Year FE & -0.001 & $0.005^{* *}$ & -0.004 & $(0.002)$ & $(0.001)$ \\
Full Set of Controls & $(0.001)$ & $(0.002)$ & $(0.003)$ & 0.25 & 0.55 \\
Observations & 0.44 & 0.43 & 0.34 & Yes & Yes \\
\hline
\end{tabular}

1. Note that all variables are in long-differences. We employ a slight abuse of notation by omitting the $\Delta$ notation to avoid clutter. $\quad 2 .{ }^{* * *},{ }^{* *},{ }^{*}$ denotes estimates statistically significant at the 1,5 or 10 percent level.

3. Robust standard errors are reported in parentheses. The standard errors have been clustered at the countryindustry level to account for within group correlation. 4. The variation in the number of observations is due to non-positive emissions reported in some industries for different countries. 
Table 5: IV Results, Aggregate Measures (Long-Differences)

\begin{tabular}{|c|c|c|c|c|}
\hline & $\begin{array}{l}\text { Prod. GHG } \\
\ln \left(G H G^{p}\right)\end{array}$ & $\begin{array}{c}\text { Cons. GHG } \\
\ln \left(G H G^{c}\right)\end{array}$ & $\begin{array}{l}\text { GHG-Production } \\
\text { Intensity Ratio }\end{array}$ & $\begin{array}{l}\text { GHG-Consumption } \\
\text { Intensity Ratio }\end{array}$ \\
\hline \multicolumn{5}{|c|}{ Panel A: Developed Countries } \\
\hline$M^{C H N}$ & $\begin{array}{c}-0.039^{* * *} \\
(0.01)\end{array}$ & $\begin{array}{c}0.046^{* * *} \\
(0.009)\end{array}$ & $\begin{array}{c}-0.044^{*} \\
(0.024)\end{array}$ & $\begin{array}{c}0.063^{* * *} \\
(0.010)\end{array}$ \\
\hline First-Stage F-Statistic & $107.2^{* * *}$ & $98.42^{* * *}$ & $30.21^{* * *}$ & $102.06^{* * *}$ \\
\hline$R^{2}$ & 0.26 & 0.43 & 0.49 & 0.658 \\
\hline Country $\times$ Year FE & Yes & Yes & Yes & Yes \\
\hline Full Set of Controls & Yes & Yes & Yes & Yes \\
\hline Observations & 941 & 941 & 941 & 941 \\
\hline \multicolumn{5}{|l|}{ Panel B: All 39 Countries } \\
\hline$M^{C H N}$ & $\begin{array}{c}-0.031^{* * *} \\
(0.008)\end{array}$ & $\begin{array}{c}0.045^{* * *} \\
(0.007)\end{array}$ & $\begin{array}{c}-0.022^{* *} \\
(0.009)\end{array}$ & $\begin{array}{c}0.052^{* * *} \\
(0.008)\end{array}$ \\
\hline First-Stage F-Statistic & $110.18^{* * *}$ & $107.29^{* * *}$ & $111.89^{* * *}$ & $110.1^{* * *}$ \\
\hline$R^{2}$ & 0.30 & 0.35 & 0.48 & 0.49 \\
\hline Country $\times$ Year FE & Yes & Yes & Yes & Yes \\
\hline Full Set of Controls & Yes & Yes & Yes & Yes \\
\hline Observations & 1060 & 1075 & 1060 & 1075 \\
\hline
\end{tabular}

$1 .{ }^{* * *},{ }^{* *},{ }^{*}$ denotes estimates statistically significant at the 1,5 or 10 percent level. $\quad 2$. Robust standard errors are reported in parentheses. The standard errors have been clustered at the country-industry level to account for within group correlation. 3. The variation in the number of observations is due to non-positive emissions reported in some industries in countries.

Table 6: IV Results, Component Measures (Long-Differences)

\begin{tabular}{|c|c|c|c|c|c|}
\hline & $\begin{array}{c}\text { Export GHG } \\
\ln \left(G H G^{x}\right)\end{array}$ & $\begin{array}{l}\text { Import GHG } \\
\ln \left(G H G^{m}\right)\end{array}$ & $\begin{array}{l}\text { GHG-Import } \\
\text { Intensity Ratio }\end{array}$ & $\begin{array}{l}\text { Domestic } \\
\ln \left(G H G^{d}\right)\end{array}$ & $\begin{array}{c}\text { Dom. Intensity } \\
\text { Ratio }\end{array}$ \\
\hline \multicolumn{6}{|c|}{ Panel A: Developed Countries } \\
\hline$M^{C H N}$ & $\begin{array}{l}-0.009 \\
(0.012)\end{array}$ & $\begin{array}{c}0.068^{* * *} \\
(0.011)\end{array}$ & $\begin{array}{c}0.059^{* * *} \\
(0.011)\end{array}$ & $\begin{array}{c}-0.043^{* *} \\
(0.009)\end{array}$ & $\begin{array}{l}-0.004 \\
(0.005)\end{array}$ \\
\hline First-Stage F-Statistic & $98.67^{* * *}$ & $91.92^{* * *}$ & $98.21^{* * *}$ & $95.31^{* * *}$ & $98.56^{* * *}$ \\
\hline$R^{2}$ & 0.46 & 0.63 & 0.58 & 0.26 & 0.66 \\
\hline Country $\times$ Year FE & Yes & Yes & Yes & Yes & Yes \\
\hline Full Set of Controls & Yes & Yes & Yes & Yes & Yes \\
\hline Observations & 936 & 941 & 941 & 939 & 939 \\
\hline \multicolumn{6}{|l|}{ Panel B: All Countries } \\
\hline$M^{C H N}$ & $\begin{array}{c}-0.017^{*} \\
(0.01)\end{array}$ & $\begin{array}{c}0.059^{* * *} \\
(0.008)\end{array}$ & $\begin{array}{c}0.061^{* * *} \\
(0.010)\end{array}$ & $\begin{array}{l}-0.016 \\
(0.017)\end{array}$ & $\begin{array}{l}-0.001 \\
(0.003)\end{array}$ \\
\hline First-Stage F-Statistic & $106.37^{* * *}$ & $106.02^{* * *}$ & $106.02^{* * *}$ & $105.09^{* * *}$ & $106.34^{* * *}$ \\
\hline$R^{2}$ & 0.47 & 0.63 & 0.53 & 0.27 & 0.64 \\
\hline Country $\times$ Year FE & Yes & Yes & Yes & Yes & Yes \\
\hline Full Set of Controls & Yes & Yes & Yes & Yes & Yes \\
\hline Observations & 1067 & 1081 & 1081 & 1049 & 1079 \\
\hline
\end{tabular}

$1 .^{* * *},{ }^{* *},{ }^{*}$ denotes estimates statistically significant at the 1,5 or 10 percent level.

2. Robust standard errors are reported in parentheses. The standard errors have been clustered at the countryindustry level to account for within group correlation. 3. The variation in the number of observations is due to non-positive emissions reported in some industries in countries. 
Table 7: Offshoring Production

\begin{tabular}{|c|c|c|}
\hline & $\begin{array}{c}\text { Broad } \\
\text { Measure }\end{array}$ & $\begin{array}{l}\text { Narrow } \\
\text { Measure }\end{array}$ \\
\hline \multicolumn{3}{|l|}{ Panel A: OLS } \\
\hline$M^{C H N}$ & $\begin{array}{c}0.49^{* * *} \\
(0.07)\end{array}$ & $\begin{array}{c}0.41^{* * *} \\
(0.06)\end{array}$ \\
\hline$M^{C H N} \times D I$ & $\begin{array}{c}-0.32^{* * *} \\
(0.09)\end{array}$ & $\begin{array}{c}-0.27^{* * *} \\
(0.07)\end{array}$ \\
\hline$R^{2}$ & 0.71 & 0.65 \\
\hline Full Set of Controls & Yes & Yes \\
\hline Country $\times$ Year FE & Yes & Yes \\
\hline Sector Trends & Yes & Yes \\
\hline Observations & 1081 & 1081 \\
\hline \multicolumn{3}{|c|}{ Panel B: DID-Median Shares } \\
\hline$D^{C H N}$ & $\begin{array}{l}1.34^{* * *} \\
(0.201)\end{array}$ & $\begin{array}{c}0.98^{* * *} \\
(0.191)\end{array}$ \\
\hline$D^{C H N} \times D I$ & $\begin{array}{c}0.13^{* * *} \\
(0.05)\end{array}$ & $\begin{array}{c}0.11^{* * *} \\
(0.027)\end{array}$ \\
\hline$R^{2}$ & 0.45 & 0.40 \\
\hline Full Set of Controls & Yes & Yes \\
\hline Country $\times$ Year FE & Yes & Yes \\
\hline Sector Trends & Yes & Yes \\
\hline Observations & 1081 & 1081 \\
\hline \multicolumn{3}{|l|}{ Panel C: DID-Full Shares } \\
\hline$M_{s}^{C H N}$ & $\begin{array}{c}0.389^{* * *} \\
(0.105)\end{array}$ & $\begin{array}{c}0.406^{* * *} \\
(0.101)\end{array}$ \\
\hline$M_{s}^{C H N} \times D I$ & $\begin{array}{c}0.134^{* * *} \\
(0.047)\end{array}$ & $\begin{array}{c}0.109^{* * * *} \\
(0.028)\end{array}$ \\
\hline$R^{2}$ & 0.45 & 0.41 \\
\hline Full Set of Controls & Yes & Yes \\
\hline Country $\times$ Year FE & Yes & Yes \\
\hline Sector Trends & Yes & Yes \\
\hline Observations & 1081 & 1081 \\
\hline
\end{tabular}

Note that all variables are in long-differences. We employ a slight abuse of notation by omitting the $\Delta$ notation to avoid clutter. $2 .^{* *},{ }^{* *},{ }^{*}$ denotes estimates statistically significant at the 1,5 or 10 percent level.

3. Robust standard errors are reported in parentheses. The standard errors have been clustered at the countryindustry level to account for within group correlation. 


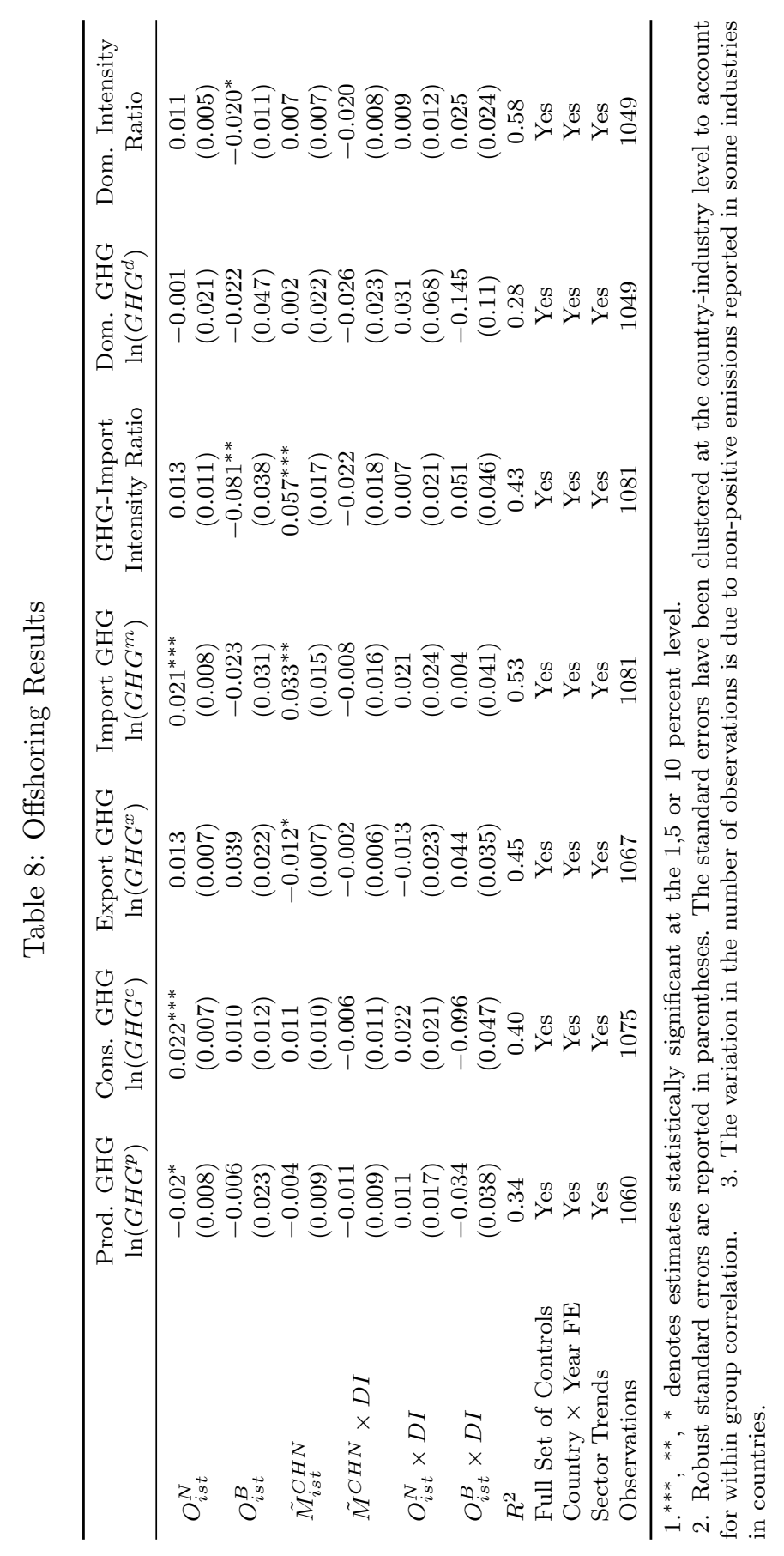




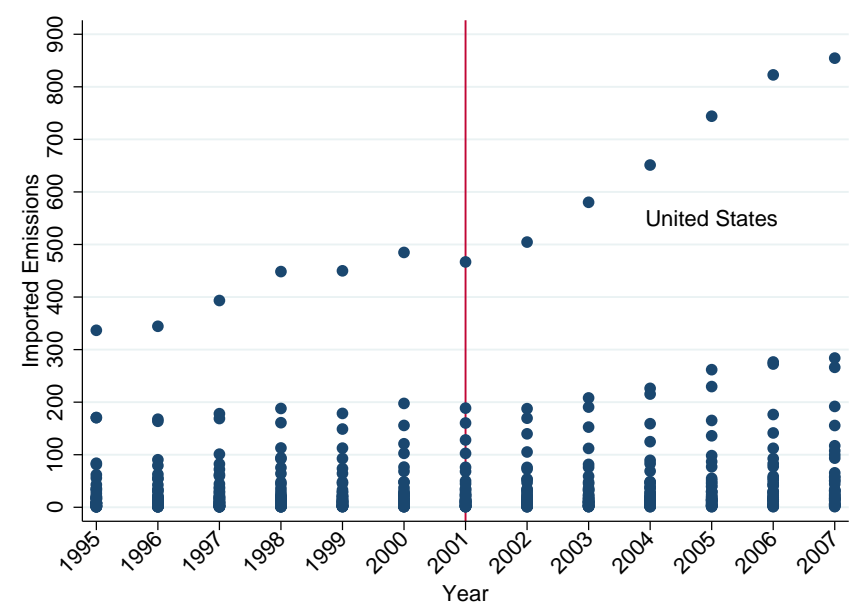

Figure A1: Imported GHG Emissions by Country (1000 Tonnes)

\section{A Appendix}

\section{A.1 Additional Estimates}

We present additional analysis and robustness checks in this appendix. Figure A1 is a scatterplot of the average annual imported emissions for each of the 39 countries in the sample (corresponds to figure 2). Almost all countries experienced an increase in the growth of imported emissions. The United States is the outlier in terms of the level of imported emissions. In figure A2, we present a scatterplot of consumption emissions and production emissions for each country. The United States is the outlier in terms of the level off emissions. Note that we investigated whether the experience of the United States was driving the empirical results by estimating a full set of specifications not including observations for the United States. The results confirm that the observations from the United States are not driving the results. 


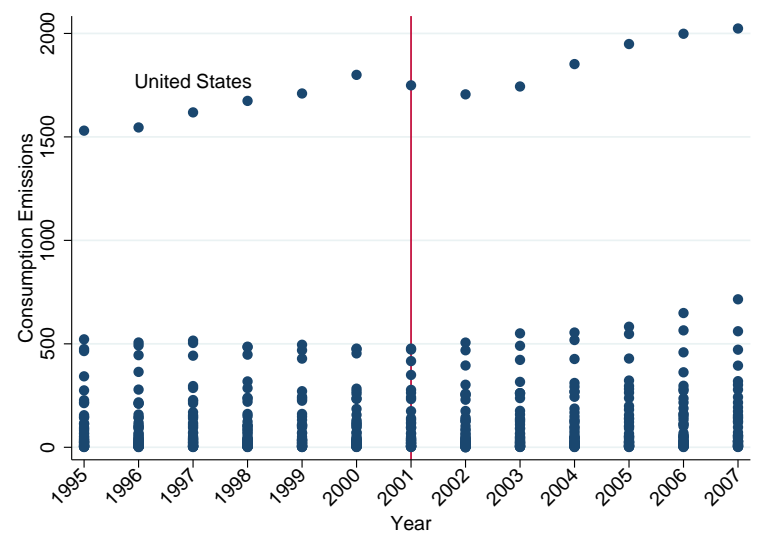

(a) Consumption-based Emission (1000 Tonnes)

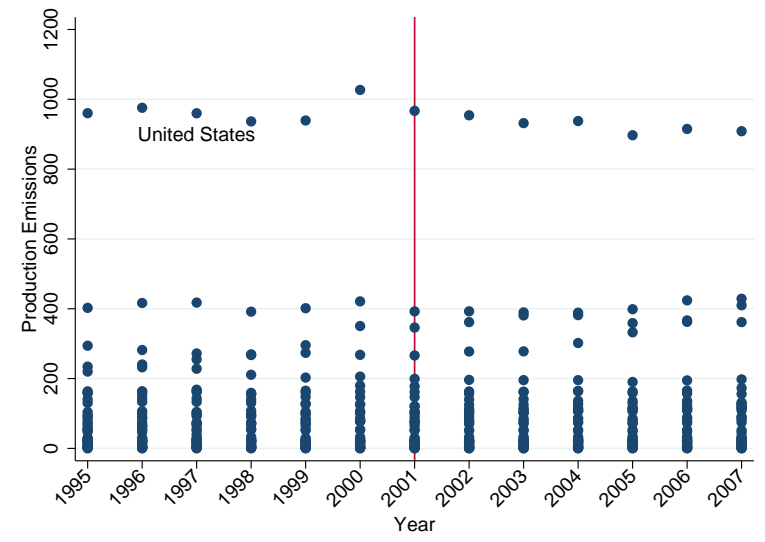

(b) Production-based Emissions

Figure A2: GHG Emissions, 1995-2007 


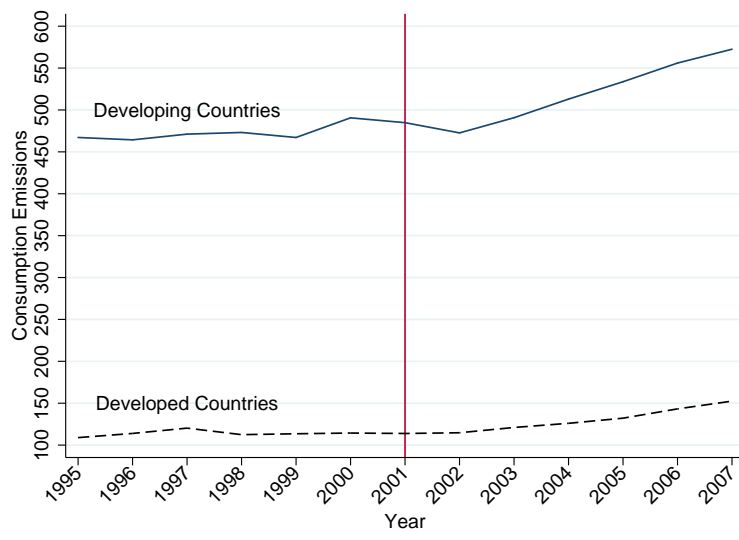

(a) Consumption-based Emission (10000 Tonnes)

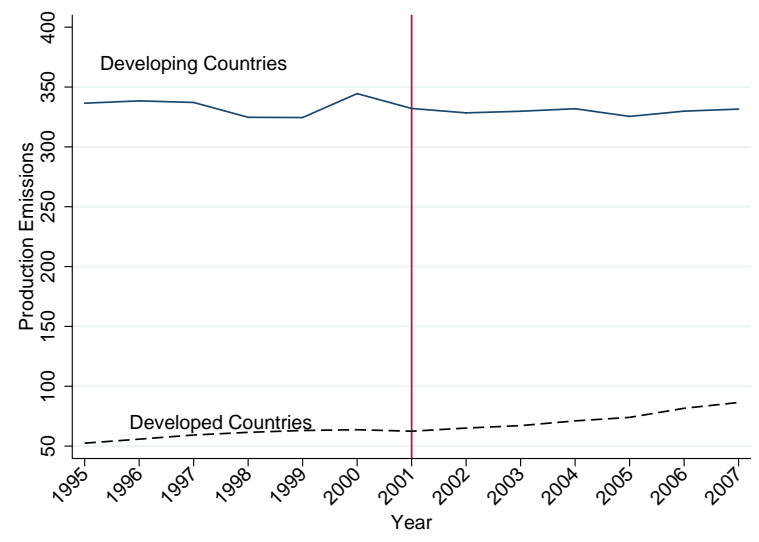

(b) Production-based Emissions

Figure A3: Aggregate GHG Emissions, 1995-2007

In addition, we report aggregate consumption and production-based emissions in figures 3(a)) and 3(b). The aggregate measure of emissions are consistent with those reported in the two panels in figure 3 which report conditional averages. The aggregate consumption emissions of both developed and developing countries tended to increase at a faster rate post 2002. Production emissions tended to decrease at a faster rate post 2000 for developing countries, while production emissions for developing countries tended to increase over the entire sample period. Note that developing countries have lower aggregate emissions relative to developed countries.

The empirical models in the paper were specified in long-differences because we were ultimately interested in learning how changes in import penetration rates affected the growth of emissions after China entered the WTO. For completeness, we also estimated a version of the baseline model in levels. Specifically, we estimated the model

$$
Y_{i s t}=\beta_{1} M_{i s t}^{C H N}+\beta_{2} D_{i}^{d e v} \times M_{i s t}^{C H N}+x_{i s t}^{\prime} \gamma+\mu_{i t}+\eta_{i s}+\epsilon_{i s t} .
$$

The results are reported in Table A2. The estimates are consistent with all of the results reported in the paper and support our argument that China's liberalised trade had a substantial effect on consumption emissions and on imported emissions. Moreover, the increase in imported emissions was not offset by a decrease in domestically produced emissions. The estimated effect on consumption emissions is greater than on production emissions.

The main results presented in the paper were estimated using data on 14 manufacturing sectors. We focused on the manufacturing sectors because they comprise the bulk of internationally trade goods and GHG emissions. For example, the 14 service sectors are not emission intensive. However, we estimated the 
baseline model using all 35 sectors as a check against the results generated using only manufacturing sectors. The estimated coefficients reported in Table A4 are consistent with those reported in table 2 although the estimated effects are slightly weaker than those reported first panel in Table 2. Including the sectors that are relatively less emission intensive or not extensively internationally traded tended to dampen the estimated effects.

We present results for the full set of control variables in Table A6. The results reported in this table for the control variables are indicative of those obtained from the other estimators and specifications. Emission levels are increasing with real output while emission intensities are decreasing. The estimates are both statistically and economically significant. Real output is the only control variable that consistently had a significant effect on the various measures of emissions. Note that we estimated specification with alternative measures of capital and labour and these various specifications produced similar results.

We present more results using our instrumental variable estimator in Table A7. We construct two additional versions of the instrument using China's import shares from different years prior to joining the WTO. Using earlier shares reduced the likelihood of encountering anticipatory trade policy changes that China may have implemented prior to joining the WTO. The first panel reports the results using imports in 1998 to construct the instrument, whereas in the second panel use imports in 1997. Using the two different instruments had little effect on the results reported in Table 6. 
Table A1: OLS Results, Aggregate Measures, Manufacturing Sectors (Levels)

\begin{tabular}{|c|c|c|c|c|}
\hline & $\begin{array}{l}\text { Prod. GHG } \\
\ln \left(G H G^{p}\right)\end{array}$ & $\begin{array}{l}\text { Cons. GHG } \\
\ln \left(G H G^{c}\right)\end{array}$ & $\begin{array}{l}\text { GHG-Production } \\
\text { Intensity Ratio }\end{array}$ & $\begin{array}{l}\text { GHG-Consumption } \\
\text { Intensity Ratio }\end{array}$ \\
\hline$M^{C H N}$ & $\begin{array}{l}-0.003 \\
(0.003)\end{array}$ & $\begin{array}{c}0.020^{* * *} \\
(0.005)\end{array}$ & $\begin{array}{l}-0.008 \\
(0.005)\end{array}$ & $\begin{array}{l}0.010^{* *} \\
(0.005)\end{array}$ \\
\hline$M^{C H N} \times D I$ & $\begin{array}{c}0 \\
(0.005)\end{array}$ & $\begin{array}{l}-0.012 \\
(0.007)\end{array}$ & $\begin{array}{c}0 \\
(0.007)\end{array}$ & $\begin{array}{c}0.004 \\
(0.006)\end{array}$ \\
\hline$R^{2}$ & 0.70 & 0.63 & 0.72 & 0.72 \\
\hline Country $\times$ Year FE & Yes & Yes & Yes & Yes \\
\hline Sector $\times$ Country FE & Yes & Yes & Yes & Yes \\
\hline Full Set of Controls & Yes & Yes & Yes & Yes \\
\hline Observations & 3705 & 3744 & 3663 & 3747 \\
\hline
\end{tabular}

$1 .^{* * *},{ }^{* *},{ }^{*}$ denotes estimates statistically significant at the 1,5 or 10 percent level.

2. Robust standard errors are reported in parentheses. The standard errors have been clustered at the country-industry level to account for within group correlation.

3. The variation in the number of observations is due to non-positive emissions reported in some industries for different countries.

Table A2: OLS Results, Component Measures, Manufacturing Sectors (Levels)

\begin{tabular}{|c|c|c|c|c|c|}
\hline & $\begin{array}{c}\text { Export GHG } \\
\ln \left(G H G^{x}\right)\end{array}$ & $\begin{array}{c}\text { Import GHG } \\
\ln \left(G H G^{m}\right)\end{array}$ & $\begin{array}{l}\text { GHG-Import } \\
\text { Intensity Ratio }\end{array}$ & $\begin{array}{c}\text { Domestic } \\
\ln \left(G H G^{d}\right)\end{array}$ & $\begin{array}{c}\text { Dom. Intensity } \\
\text { Ratio }\end{array}$ \\
\hline$M^{C H N}$ & $\begin{array}{c}0.005 \\
(0.004)\end{array}$ & $\begin{array}{c}0.021^{* * *} \\
(0.006)\end{array}$ & $\begin{array}{c}0.020^{* *} \\
(0.009)\end{array}$ & $\begin{array}{l}0.019^{*} \\
(0.010)\end{array}$ & $\begin{array}{c}0.007^{* *} \\
(0.002)\end{array}$ \\
\hline$M^{C H N} \times D I$ & $\begin{array}{l}-0.008 \\
(0.007)\end{array}$ & $\begin{array}{c}0.001 \\
(0.007)\end{array}$ & $\begin{array}{c}0.011 \\
(0.010)\end{array}$ & $\begin{array}{l}-0.040 \\
(0.017)\end{array}$ & $\begin{array}{c}-0.013^{* * *} \\
(0.004)\end{array}$ \\
\hline$R^{2}$ & 0.73 & 0.77 & 0.78 & 0.68 & 0.73 \\
\hline Country $\times$ Year FE & Yes & Yes & Yes & Yes & Yes \\
\hline Sector $\times$ Country FE & Yes & Yes & Yes & Yes & Yes \\
\hline Full Set of Controls & Yes & Yes & Yes & Yes & Yes \\
\hline Observations & 3736 & 3778 & 3778 & 3624 & 3774 \\
\hline
\end{tabular}

$1 .^{* * *},{ }^{* *},{ }^{*}$ denotes estimates statistically significant at the 1,5 or 10 percent level. 2 . Robust standard errors are reported in parentheses. The standard errors have been clustered at the country-industry level to account for within group correlation.

3. The variation in the number of observations is due to non-positive emissions reported in some industries for different countries. 
Table A3: OLS Results, Aggregate Measures, 35 Sectors (Long-Differences)

\begin{tabular}{|c|c|c|c|c|}
\hline & $\begin{array}{l}\text { Prod. GHG } \\
\ln \left(G H G^{p}\right)\end{array}$ & $\begin{array}{l}\text { Cons. GHG } \\
\ln \left(G H G^{c}\right)\end{array}$ & $\begin{array}{l}\text { GHG-Production } \\
\text { Intensity Ratio }\end{array}$ & $\begin{array}{l}\text { GHG-Consumption } \\
\text { Intensity Ratio }\end{array}$ \\
\hline$M^{C H N}$ & $\begin{array}{c}-0.012^{* * *} \\
(0.004)\end{array}$ & $\begin{array}{c}0.014^{* * *} \\
(0.003)\end{array}$ & $\begin{array}{l}-0.011^{* *} \\
(0.005)\end{array}$ & $\begin{array}{l}0.011^{* *} \\
(0.005)\end{array}$ \\
\hline$M^{C H N} \times D I$ & $\begin{array}{c}0.011 \\
(0.006)\end{array}$ & $\begin{array}{c}-0.011^{* *} \\
(0.007)\end{array}$ & $\begin{array}{c}0.013 \\
(0.012)\end{array}$ & $\begin{array}{l}-0.006 \\
(0.006)\end{array}$ \\
\hline$R^{2}$ & 0.24 & 0.28 & 0.32 & 0.37 \\
\hline Country $\times$ Year FE & Yes & Yes & Yes & Yes \\
\hline Sector Trends & Yes & Yes & Yes & Yes \\
\hline Full Set of Controls & Yes & Yes & Yes & Yes \\
\hline Observations & 2561 & 2627 & 2541 & 2626 \\
\hline
\end{tabular}

$1 .^{* * *},{ }^{* *},{ }^{*}$ denotes estimates statistically significant at the 1,5 or 10 percent level.

2. Robust standard errors are reported in parentheses. The standard errors have been clustered at the country-industry level to account for within group correlation. 3. The variation in the number of observations is due to non-positive emissions reported in some industries for different countries.

Table A4: OLS Results, Component Measures, 35 Sectors (Long-Differences)

\begin{tabular}{lccccc}
\hline & $\begin{array}{c}\text { Export GHG } \\
\ln \left(G H G^{x}\right)\end{array}$ & $\begin{array}{c}\text { Import GHG } \\
\ln \left(G H G^{m}\right)\end{array}$ & $\begin{array}{c}\text { GHG-Import } \\
\text { Intensity Ratio }\end{array}$ & $\begin{array}{c}\text { Domestic } \\
\ln \left(G H G^{d}\right)\end{array}$ & $\begin{array}{c}\text { Dom. Intensity } \\
\text { Ratio }\end{array}$ \\
\hline$M^{C H N}$ & -0.003 & $0.011^{* *}$ & $0.01^{* *}$ & -0.004 & $0.004^{*}$ \\
$M^{C H N} \times D I$ & $(0.007)$ & $(0.005)$ & $(0.005)$ & $(0.006)$ & $(0.002)$ \\
$R^{2}$ & 0.021 & $0.021^{* *}$ & $0.028^{* *}$ & -0.024 & -0.007 \\
Country $\times$ Year FE & $(0.016)$ & $(0.009)$ & $(0.011)$ & $(0.021)$ & $(0.005)$ \\
Sector Trends & 0.16 & 0.29 & 0.30 & 0.26 & 0.35 \\
Full Set of Controls & Yes & Yes & Yes & Yes & Yes \\
Observations & Yes & Yes & Yes & Yes & Yes \\
\hline
\end{tabular}

$1 .^{* *},{ }^{* *},{ }^{*}$ denotes estimates statistically significant at the 1,5 or 10 percent level. 2 . Robust standard errors are reported in parentheses. The standard errors have been clustered at the country-industry level to account for within group correlation. 3. The variation in the number of observations is due to nonpositive emissions reported in some industries for different countries. 
Table A5: OLS Results, Aggregate Measures, Full Results (Long-Differences)

\begin{tabular}{lcccc}
\hline & $\begin{array}{c}\text { Prod. GHG } \\
\ln \left(G H G^{p}\right)\end{array}$ & $\begin{array}{c}\text { Cons. GHG } \\
\ln \left(G H G^{c}\right)\end{array}$ & $\begin{array}{c}\text { GHG-Production } \\
\text { Intensity Ratio }\end{array}$ & $\begin{array}{c}\text { GHG-Consumption } \\
\text { Intensity Ratio }\end{array}$ \\
\hline \multirow{2}{*}{$M^{C H N}$} & $-0.014^{* *}$ & $0.027^{* * *}$ & $-0.015^{* *}$ & $0.025^{* * *}$ \\
$M^{C H N} \times D I$ & $(0.006)$ & $(0.005)$ & $(0.007)$ & $(0.006)$ \\
& 0.006 & $-0.014^{*}$ & 0 & -0.011 \\
Output & $(0.007)$ & $(0.008)$ & $(0.008)$ & $(0.008)$ \\
& $0.102^{* *}$ & $0.0409^{* * *}$ & $-0.929^{* * *}$ & $-0.625^{* * *}$ \\
Capital Share & $(0.052)$ & $(0.068)$ & $(0.074)$ & $(0.059)$ \\
& 0.020 & -0.006 & 0.050 & 0.008 \\
Hours Worked & $(0.028)$ & $(0.033)$ & $(0.035)$ & $(0.030)$ \\
& $0.097^{*}$ & $-0.171^{* * *}$ & $0.18^{* *}$ & $-0.127^{* *}$ \\
Low Skill Worker & $(0.052)$ & $(0.063)$ & $(0.077)$ & $(0.051)$ \\
$R^{2}$ & 0.101 & $-0.006^{*}$ & 0.076 & -0.014 \\
Country $\times$ Year FE & $(0.119)$ & $(0.075)$ & $(0.123)$ & $(0.061)$ \\
Observations & 0.32 & 0.36 & 0.46 & 0.55 \\
\hline & Yes & Yes & Yes & Yes \\
\hline
\end{tabular}

$1 .^{* * *},{ }^{* *},{ }^{*}$ denotes estimates statistically significant at the 1,5 or 10 percent level.

2. Robust standard errors are reported in parentheses. The standard errors have been clustered at the country-industry level to account for within group correlation. 3. The variation in the number of observations is due to non-positive emissions reported in some industries in countries.

Table A6: OLS Results, Component Measures, Full Results (Long-Differences)

\begin{tabular}{lccccc}
\hline & $\begin{array}{c}\text { Export GHG } \\
\ln \left(G H G^{x}\right)\end{array}$ & $\begin{array}{c}\text { Import GHG } \\
\ln \left(G H G^{m}\right)\end{array}$ & $\begin{array}{c}\text { GHG-Import } \\
\text { Intensity Ratio }\end{array}$ & $\begin{array}{c}\text { Domestic } \\
\ln \left(G H G^{d}\right)\end{array}$ & $\begin{array}{c}\text { Dom. Intensity } \\
\text { Ratio }\end{array}$ \\
\hline$M^{C H N}$ & $0.011^{* *}$ & $0.038^{* * *}$ & $0.036^{* * *}$ & -0.011 & $0.006^{* * *}$ \\
$M^{C H N} \times D I$ & $(0.005)$ & $(0.005)$ & $(0.009)$ & $(0.010)$ & $(0.002)$ \\
& -0.012 & -0.002 & 0.003 & 0.001 & $-0.012^{* *}$ \\
Output & $(0.008)$ & $(0.008)$ & $(0.011)$ & $(0.018)$ & $(0.006)$ \\
& $0.735^{* * *}$ & $0.145^{* * *}$ & $-0.941^{* * *}$ & $0.693^{* * *}$ & $-0.209^{* * *}$ \\
Capital Share & $(0.081)$ & $(0.050)$ & $(0.058)$ & $(0.124)$ & $(0.032)$ \\
& 0.024 & -0.038 & 0.040 & 0.118 & -0.006 \\
Hours Worked & $(0.053)$ & $(0.027)$ & $(0.037)$ & $(0.186)$ & $(0.016)$ \\
& 0.097 & -0.002 & 0.021 & -0.057 & 0.045 \\
Low Skill Worker & $(0.087)$ & $(0.062)$ & $(0.068)$ & $(0.14)$ & $(0.036)$ \\
$R^{2}$ & 0.035 & -0.062 & -0.021 & 0.118 & -0.006 \\
Country $\times$ Year FE & $(0.094)$ & $(0.123)$ & $(0.129)$ & $(0.185)$ & $(0.016)$ \\
Observations & 0.44 & 0.38 & 0.55 & 0.24 & 0.55 \\
& Yes & Yes & Yes & Yes & Yes \\
\hline
\end{tabular}

$1 .^{* * *},{ }^{* *},{ }^{*}$ denotes estimates statistically significant at the 1,5 or 10 percent level. 2 . Robust standard errors are reported in parentheses. The standard errors have been clustered at the country-industry level to account for within group correlation. 3. The variation in the number of observations is due to nonpositive emissions reported in some industries in countries. 
Table A7: Additional IV Results (Long-Differences)

\begin{tabular}{lccccc}
\hline & $\begin{array}{c}\text { Prod. GHG } \\
\ln \left(G H G^{p}\right)\end{array}$ & $\begin{array}{c}\text { Cons. GHG } \\
\ln \left(G H G^{c}\right)\end{array}$ & $\begin{array}{c}\text { Import GHG } \\
\ln \left(G H G^{m}\right)\end{array}$ & $\begin{array}{c}\text { GHG-Import } \\
\text { Intensity Ratio }\end{array}$ & $\begin{array}{c}\text { Dom. GHG } \\
\ln \left(G H G^{d}\right)\end{array}$ \\
\hline Panel A: 1998 Trade & & & & & \\
$M^{C H N}$ & $-0.043^{* * *}$ & $0.025^{* * *}$ & $0.032^{* * *}$ & $0.12^{* * *}$ & -0.022 \\
First-Stage F-Statistic & $(0.010)$ & $(0.001)$ & $(0.008)$ & $(0.019)$ & $(0.018)$ \\
$R^{2}$ & $58.16^{* * *}$ & $59.13^{* * *}$ & $57.18^{* * *}$ & $56.70^{* * *}$ & $56.18^{* * *}$ \\
Country $\times$ Year FE & 0.24 & 0.29 & 0.63 & 0.02 & 0.16 \\
Observations & Yes & Yes & Yes & Yes & Yes \\
\hline Panel B: 1997 Trade & 1067 & 1086 & 1092 & 1086 & 1053 \\
\hline$M^{C H N}$ & $-0.048^{* * *}$ & $0.019^{* * *}$ & $0.027^{* *}$ & $0.13^{* * *}$ & 0.021 \\
First-Stage F-Statistic & $(0.012)$ & $(0.007)$ & $(0.009)$ & $(0.022)$ & $(0.019)$ \\
$R^{2}$ & $53.56^{* * *}$ & $54.29^{* * *}$ & $42.94^{* * *}$ & $52.32^{* * *}$ & $50.17^{* * *}$ \\
Country $\times$ Year FE & 0.21 & 0.30 & 0.63 & 0.02 & 0.16 \\
Sector Trends & Yes & Yes & Yes & Yes & Yes \\
Observations & Yes & Yes & Yes & Yes & Yes \\
\hline
\end{tabular}

$1 .^{*}$ denotes estimates statistically significant at the 5 percent level or smaller.

2. Robust standard errors are reported in parentheses. The standard errors have been clustered at the country-industry level to account for within group correlation. 3. The variation in the number of observations is due to non-positive emissions reported in some industries in countries. 